\title{
(2) \\ The Arson of a Museum: Ethnography of historical experience and plant fiber use in northern Coclé Province, Panama
}

\author{
Nina K. Müller-Schwarze
}

\section{Research}

\begin{abstract}
The use of tree cambium to make cucua dance outfits attracted the attention of international plant and culture conservationists. Scholarly narratives, media interpretations, and publications for the tourism market about cucua often reiterate racialized colonial categories as the origin point for a history construed as Panamanian. Implementation of conservation programs, like the construction of a museum and cultural center, ignored existing social structures among dancers. Arsonists allegedly destroyed the museum. This article presents data collected in anthropological participant observation methodologies and describes why conservation programs were rejected through the ethnography of historical experience that shows how people make sense of the past. Local explanations of plant uses that include power accessed through the ruptures of social structures during liminal times, such as Spanish colonialism, are real and not just symbolic. This article places cucua plant use in cultural context with other plant fibers used in northern Coclé for baskets, all called "weaving."
\end{abstract}

\section{Introduction}

Widespread understandings of ethnobotanical knowledge as corresponding to a particular cultural or ethnic group oversimplify anthropological theory. This has real consequences, as plant preservation happens not only within the context of the available plant species in the surrounding landscape, but also within the perspectives and conversations of humans who agree as to which species ought to be cared for and how. International preservation initiatives are often aimed at people perceived to be a group defined as an ethnicity or a village. Brubaker $(2004: 16)$ correctly describes that much is at stake when the categories we use to describe social phenomena, such as labels for ethnicities or groups, are assumed to be true and essential. "Groups" understood to have clear boundaries are not universally true forms (Müller-Schwarze 2015), but rather appear at specific times in history (Brubaker 2004:45) and become objects under scholarly gazes (Foucault 1972). Brubaker (2004) encourages discussion of social belonging and verbs that relate activities instead of a priori assuming that people can be discussed with an ascribed label or category. Who are the people that create discourses about plant use and social belonging? How are discourses about plant use and conservation created and enacted?

Culture has often been the locus of conflict (Mamdani 1996). This article not only records ethnobotanical data, but also describes the specific ways that expectations of plant preservation in discourses about culture resulted in the alleged arson of a museum. The village of San Miguel Centro in northern Coclé, Panama, is known for dancers who wear an outfit made from the inner cambium of the cucua tree and decorated with plant dyes. The local term cucua refers to various trees, the cloth material made from the cambium, the dance, and the dancers. Historical documentation confirms continuity in plant and fiber utilization (Müller-Schwarze 2015), yet narratives about the

\section{Correspondence}

Nina K. Müller-Schwarze, Southern Food and Beverage Museum, New Orleans, Lousiana, U.S.A. nmullers@tulane.edu

Ethnobotany Research \& Applications 14:259-288 (2015)

Published: 28 October 2015

http://dx.doi.org/10.17348/era.14.0.259-288 
past differ. International interest in preservation of cucua practices resulted in the construction and subsequent end of a museum, as outsiders intent on treating people as an arbitrarily defined group did not respect the existing social structures among dancers and artisans.

This article describes the intersubjective interplay of expectations and stereotypes enacted through the social processes of plant conservation. Cucua practices are located within various conversations that interpret and inform identification practices today. History set in linear time seeks an origin point (Foucault 1972), and scholars, journalists, and marketers for the tourism trade who describe Coclé practices seek and interpret ethnogenesis origins in the external forms of objects made from plant fibers which thereby become the center of materialist interpretations about geographical, cultural, and linguistic origins for the Panamanian population. Rural areas are understood as repositories of the past solely in perspectives formed in colonial centers that characterize countryside areas as founts of resources in order to support extractive colonial and neocolonial economies (Müller-Schwarze 2015). Plant conservation strategies in the case of cucua portrayed this rural area as a repository of the national Panamanian past and expected local people to be stewards of this perceived origin point. Indigenous people within states are asked to demonstrate what Foucault (1972:21) terms "a special temporal status," and people associated with plant knowledge are often located in an unchanging time associated with the past.

This article, however, describes the ways local people utilize plants for material objects as adaptation to historical experience and is therefore ethnography of historical experience. Local people are not understood here as solely the occupants of San Miguel Centro village, but rather anyone who participates in discourses about cucua. The past is discussed in the present, and this article documents such discourses. Adaptation, creativity, and versatility have ensured the preservation of plant fiber use and knowledge. Artisans and dancers describe cucua dances and outfits as means to survive Spanish colonialism in a historical narrative that empowers rural people today.

People in San Miguel Centro not only prepare dance outfits from plant materials for performances; they also use baskets, rope, hats, and other items made from plant fibers in quotidian life in practices found throughout northern Coclé. Artisan and dancer explanations about the meaning of designs on the plant-fiber cucua outfit reflect position of self, and therefore understandings of human ontology, within the surrounding ecology and identification with the plant and animal world. Central Panama has many microhabitats, and thus plant preservation and cultural uses of plant species are extremely localized. Cucua practices need to be understood within the context of basketry practices found throughout northern Coclé. People that care for, harvest, prepare, and manufacture plant fibers are called vine artisans (artesanos de bejucos). Such specialists have intimate knowledge of their home in the surrounding forest that includes observations about the habitats that specific plants live in. The northern Coclé term tejidos translates as plants used for fiber or the cultural materials and products made from the raw materials available in the surrounding ecology. The plant materials for weaving are collectively called vines (bejucos). This article presents ethnohistorical evidence that relates local understandings of plant fiber use as empowerment and the means to survive challenging historical circumstances.

\section{Methods}

Data were collected in various areas of northern Coclé, Panama (Figure 1), through intermittent participant observation and interviews over the last decade. I arrived in La Martillada as a Peace Corps volunteer (1999-2001) and first visited San Miguel Centro as a guest of fellow Peace Corps volunteer Alon Terry who worked with cucua artisans in a small business development program. I was impressed with the talents and skills of cucua dancers and artisans I met and realized that there is interesting information here, yet took time in my search for what it means. Most authors on the subject had not spent time living in a northern Coclé community and therefore seemed unfamiliar with the social context wherein plant use happens. I have observed events and experiences related to cucua intermittently over the last fifteen years and found that the media and scholarly narratives about northern Coclé plant use that I read followed predictable tropes that reiterated racialized colonial categories. My central question became: how could one describe ethnobotanical data without repeating the narratives that ascribe plant knowledge to a "group" and that present local people as unchanging and outside of time?

Data were mainly collected in the village of La Martillada, with excursions to the village of San Miguel Centro, the village of Lurá, and in a survey of 55 villages in the Indio River watershed conducted in 2005 (Müller-Schwarze 2008). Informed consent was obtained in relation to this research through Tulane University. Specific weavers and artisans, named in the article, demonstrated their techniques to me. Lourdes María Barsallo provided many ethnohistorical materials from the National Lottery Archive in Penonomé. I collected plant voucher specimens together with members of the Alveo Nuñez family, after receiving permission from the Panamanian Environmental Protection Agency (Autoridad del Medio Ambiente [ANAM]). These plants are housed in herbaria at either Tulane University (NO) or the University of Panama (PMA). I document and discuss the linguistic implications of local terms, which are presented here in bold. 

experience and plant fiber use in northern Coclé Province, Panama

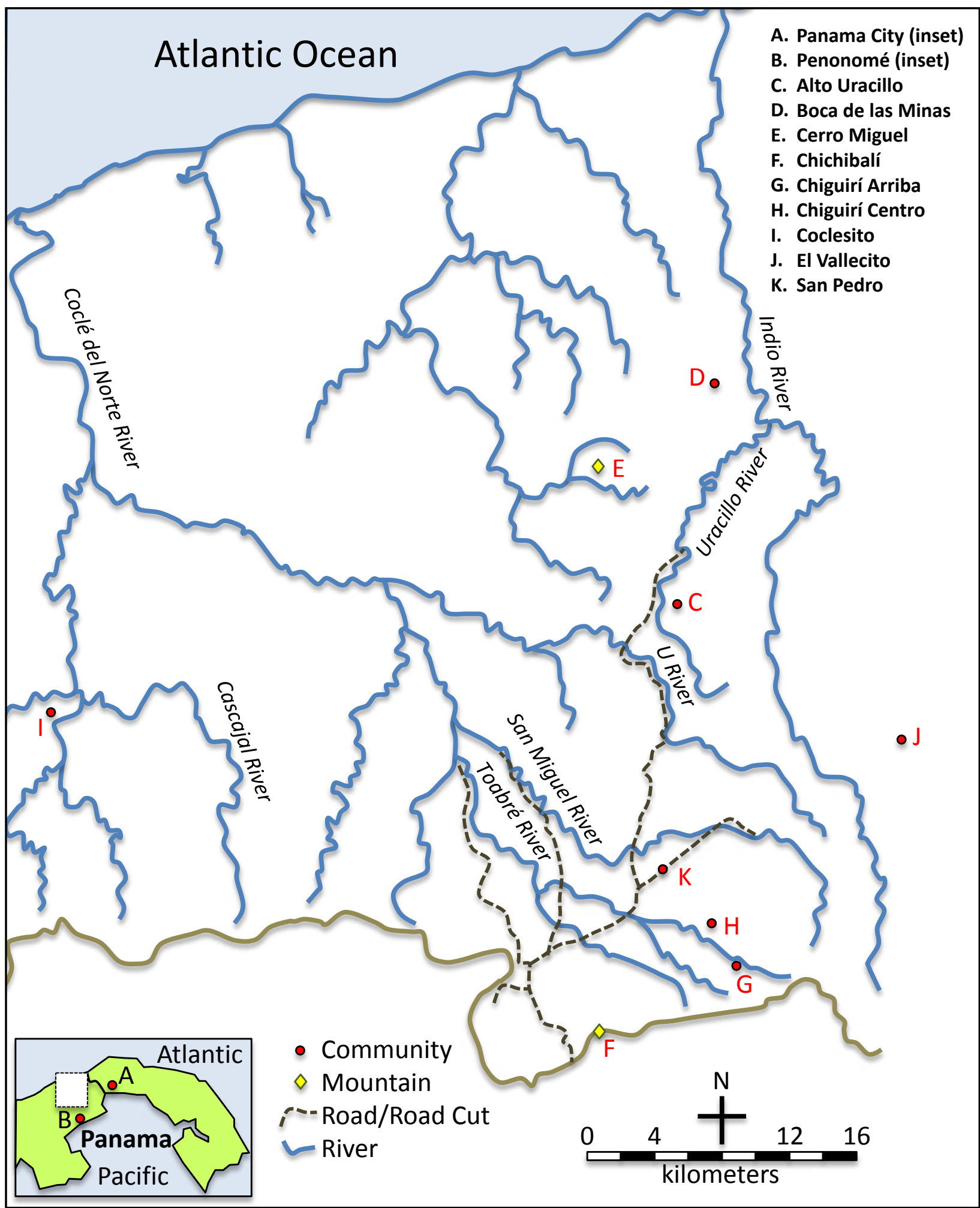

Figure 1. Study area in northern Coclé Province, Panama. Villages are located along rivers; dirt roads now connect some of these villages. 


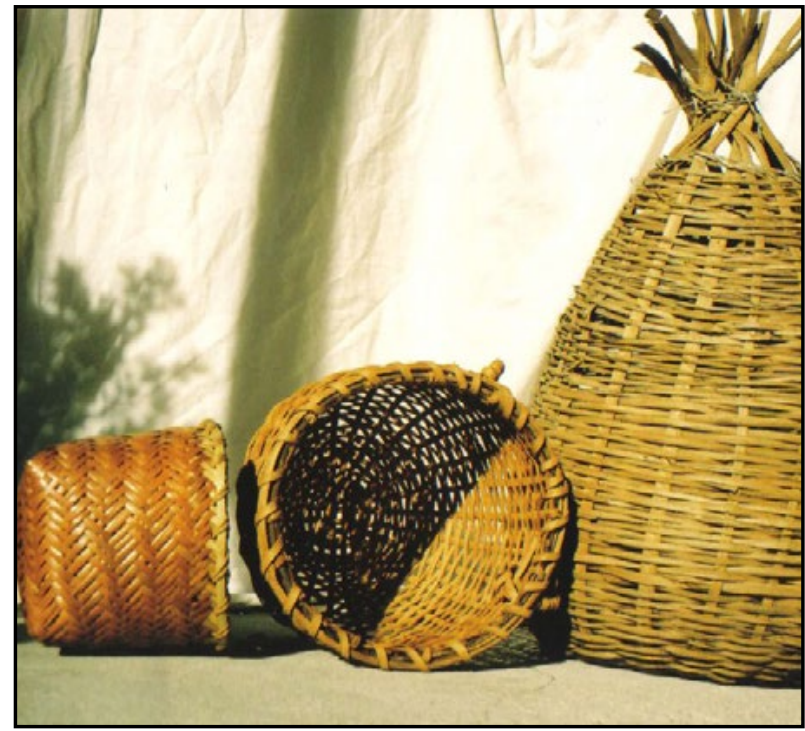

Figure 2. Basketry used in quotidian life in northern Coclé, Panama, includes a strainer, the churuco coffee harvesting basket, and the nasa fish trap. Maria Rosario Gil in San Miguel Centro made this strainer.

This article is written in memory of Asunción "Sencio" Alveo Nuñez, who patiently engaged my requests to learn about basketry and plants. He passed away in 2006 .

\section{Results}

\section{Description of utilitarian baskets}

Baskets are used in quotidian life for carrying, collecting, trapping, cooking, and storing. Weavers in northern Coclé villages (such as La Martillada and Sabana Larga) make motete carrying cases worn on the back, churuco coffee collecting baskets, nasa crustacean traps, colador woven strainers, and canasta woven all-purpose baskets (Figure 2) from plant fibers.

Agriculturalists use a motete, a large woven, open-topped basket. This is worn with two majagua fiber or cloth straps over the shoulders to carry harvested plantains or root crops from fields (Figure 3).

Coffee is harvested with a specific basket, the churuco. The churuco is regularly used and manufactured because coffee is a cash crop sold to larger markets via the road. Extended families enter coffee groves to pick red coffee berries into their churucos. The coffee picker passes a rope through the two handles of the churuco and ties it around the waist. The rounded basket stays at waist level in front of the picker. The red coffee berries are transported in these baskets to houses, where the berries are sun-dried spread out on sheets of cloth on the ground. Specific villagers who are businessmen buy dried and red

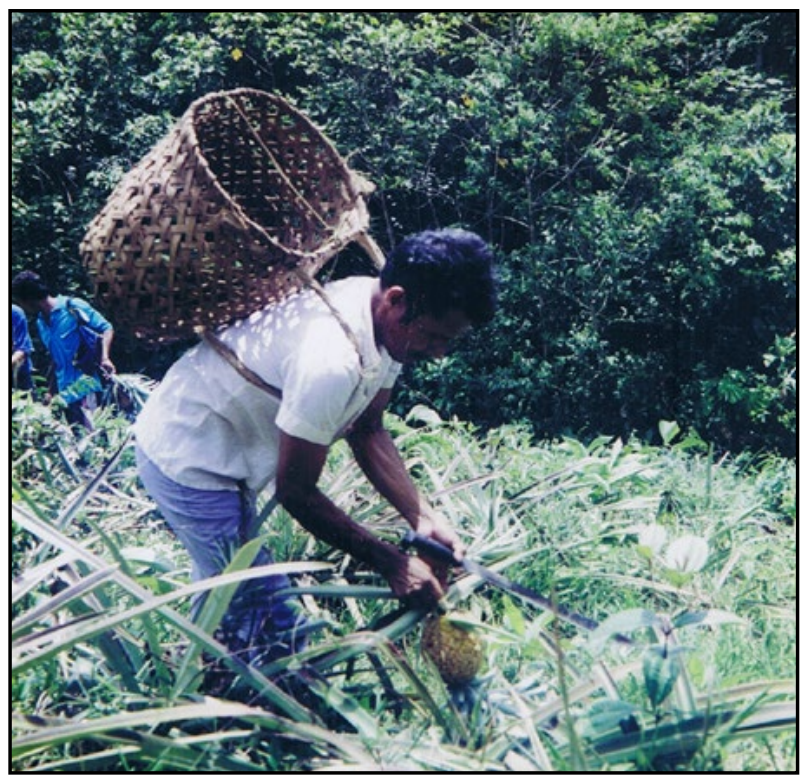

Figure 3. A man harvests pineapples into a motete, a large, open-topped basket. Sabana Larga, Coclé, Panama, June 2000.

coffee and then sell them in bulk to a coffee roaster via the road or road cut that passes through some villages.

The nasa crustacean trap is placed into the edge of a river or stream, where it is tied to a stake and filled with bait. Crustaceans and small fish enter the narrow opening and become trapped; the fisherman returns to untie the narrow opening to harvest the catch.

People cook with a variety of woven strainers (coladores). Each size corresponds to a specific kitchen task. A small strainer is widely used to drain the spice achiote (Bixa orellana L.) flavoring from oil; villagers report the strainer size as convenient. Many households tend to strain coffee with a piece of manufactured cloth on a rounded metal hanger (coladera) instead of the woven plant fiber coffee strainers, yet elder weavers remember how to make the medium-size coffee strainers. Fermented corn is processed into an alcoholic drink (chicha) which is passed through a larger strainer.

Baskets are made in both round and square shapes with handles. Small baskets were used for carrying items to market, yet villagers observe that baskets are often replaced by plastic bags today. Baskets (canastas) often hang from house rafters and are used for storage. In northern Coclé, several words sometimes refer to the same meaning; for example, handles on baskets are called agarradero and hico, and these linguistic data reveal much in the context of scholarly interpretations of indigenous continuities in the area. 


\section{Müller-Schwarze - The Arson of a Museum: Ethnography of historical experience and plant fiber use in northern Coclé Province, Panama}

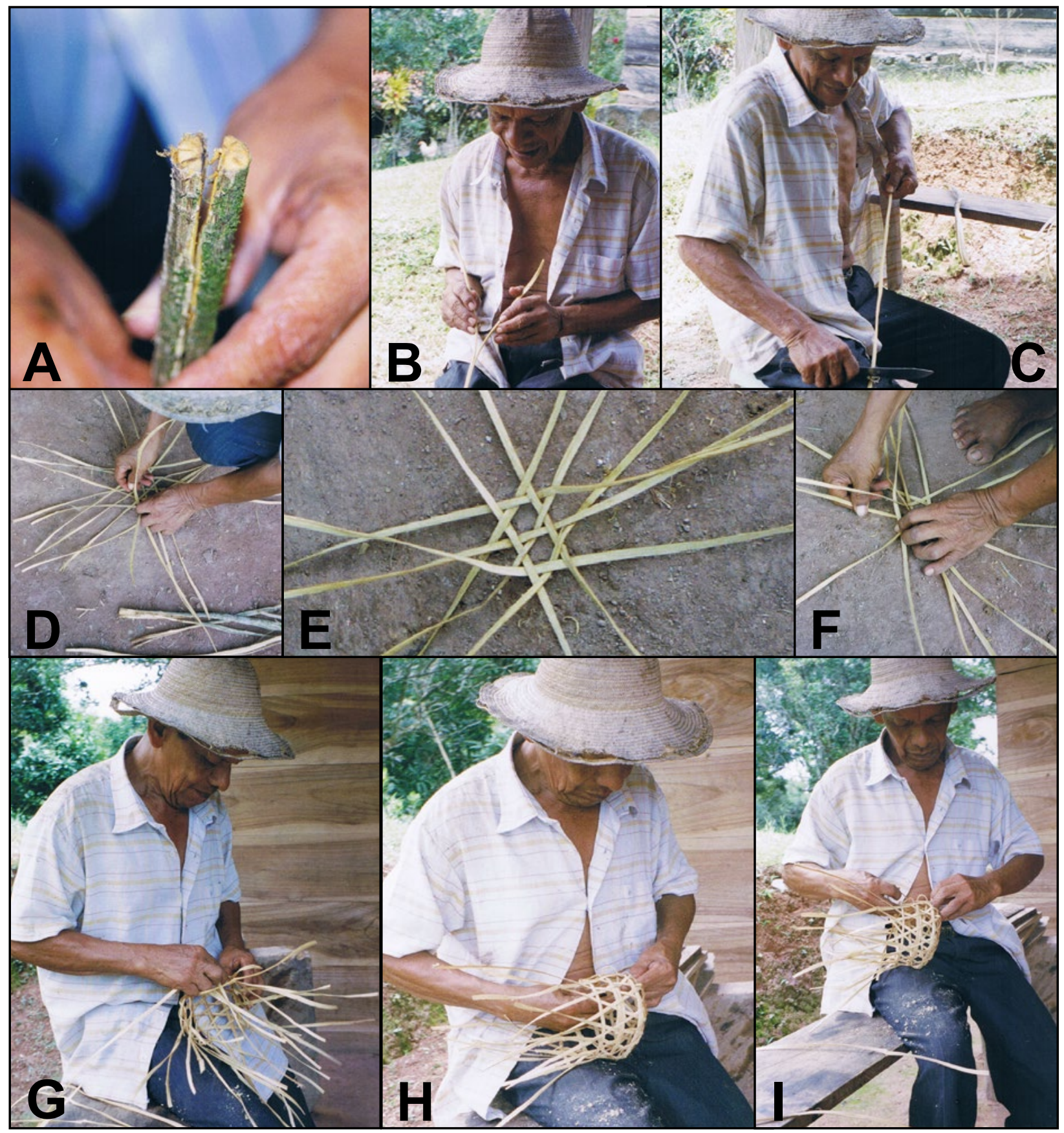

Figure 4. Asunción "Sencio" Alveo Nuñez demonstrates making a small version of a motete basket in La Martillada, Coclé, Panama. The weaver needs about $4 \mathrm{~m}$ of vine for a motete. He removes the bark and pulls along the natural divides (las venas). The artisan then presses a knife blade into the cross, which the vine shows when cut in cross section, and pulls the four sides apart while carefully gauging the pressure as too much or too little could cause an uneven division of the vine (A). The weaver turns the vine as he pulls it apart (B). A knife serves to scratch off (rajar) any remaining heartwood (C). Weavers prefer pieces with few branches, as they note these interfere with the knife scraping. The resulting pieces of prepared vine (bejuco rayado) are the raw material for the motete. The artisan creates a crossed warp weave (D-F), bends the weave at a right angle to the ground to create the lower corner edge of the motete $(\mathbf{G})$, and continues to weave vertically $(\mathbf{H}-\mathbf{I})$. Finally, the weaver doubles back and weaves down, which covers the hexagonal holes about halfway and creates an upper edge for the motete. The artisan may make the top rim from a piece of vine with bark intact around which other prepared vine is wrapped. 


\section{Manufacturing baskets}

Each weaver has specific preferences and styles in weaving, although some general trends can be observed. Asunción "Sencio" Alveo Nuñez made motetes with marica (Tanaecium pyramidatum (Rich.) L.G.Lohmann), a woody vine harvested for thick and straight pieces because he found that knots (ñoma) or joints made the vine too twisty and fibrous for weaving.

The weaver needs about $4 \mathrm{~m}$ of vine for a motete. Asunción "Sencio" Alveo Nuñez removed the bark and pulled along the natural divides (las venas). He then pressed a knife blade into the cross, which the vine shows when cut in cross section, and pulled the four sides apart while carefully gauging the pressure as too much or too little could cause an uneven division of the vine (Figure 4). He turned the vine as he pulled it apart. He scratched off with a knife any remaining heartwood. He preferred pieces with few branches, as he reported that they interfere with the knife-scraping process. The resulting pieces of prepared vine (bejuco rayado) are the raw material for the motete.

Once the vine had been scratched (rayado), it took Asunción "Sencio" Alveo Nuñez about one day to make a motete or a churuco. He explained that the artisan can walk away and return; simply wetting the bejuco rayado with water restores its flexibility. The weaver worked on the ground and kept the heart of the vine facing the other heart, so that the fibers did what Asunción "Sencio" Alveo Nuñez described as "sticking together." Asunción "Sencio" Alveo Nuñez made a row of interlocking shapes (Figure 3 ), or crossed warp weave, and then bent the weave at a right angle to the ground to create the lower corner edge of the motete and continued to weave the same shapes vertically. Finally, the motete received an upper edge by doubling back and weaving back down, which covered the hexagonal holes about halfway. Asunción "Sencio" Alveo Nuñez explained to me that the top rim may be made from a piece of vine with bark intact, around which other prepared vine is wrapped. The motete is woven in an open hexagonal lattice plait (sensu O'Neale 1963[1932]:76, Bernstein 2003:14) or crossed warp (sensu Mason 1988[1904]:71), similar to other lightweight carrying baskets manufactured across northern South America (i.e., Nordensköld 1924 in O'Neale 1963[1932]:76).

Weavers in Sabana Larga and La Martillada use thick marica vines prepared as bejuco rayado-with additional knife scratching on the vine strips for a tighter weaveto make the churuco coffee harvesting basket. The artisan weaves a single, thin, long prepared vine (bejuco rayado) through four other prepared vines laid parallel on the ground. The weaver then presses this weave tight. More bejucos rayados are added vertically, as one long prepared vine strip is woven horizontally around the basket. The long vine is doubled back over the top rim and woven back down again. A thicker vine circles the rim bor- der at the top. Two vines wrapped tightly within other vines make the handles (agarraderas, garraderas, or hico). The churuco can be described comparatively as a wicker weave (sensu Bernstein 2003:14) with a coil and knot border (sensu Mason 1988[1904]:127) at the top rim.

Weavers also use the marica vine to manufacture the nasa crustacean trap (Figure 1). La Martillada artisans lay the pieces of prepared vine (bejuco rayado) flat across their upper thigh and then press a knife along the surface to scratch off (raspar) fibrous material before beginning, which Asunción "Sencio" Alveo Nuñez described as "tightening the weave." The weaver interlaces the plant fibers around a glass bottle to create a long cylindrical shape from four vertical vines that are the warp and one long thin prepared vine that is woven under and over each warp around the form of the vessel continuously. The artisan removes the bottle and doubles the weaving back. The weave is continued in a bulbous shape that creates the bottom of the crustacean trap. An opening remains when the glass bottle is removed; this is where the animals enter the trap. Making a nasa may take two days. The nasa weave can be compared to a plain twine (sensu Mason 1988[1904]:72, 123) or wicker weave (sensu Bernstein 2003:14, O'Neale 1963[1932]) and to descriptions of similar "fish traps" in other areas (i.e, Cooper 1949, Nordenskiöld 1927).

Descriptions of weaving need to mention the individual artisan, as each has their own preferences and innovations. In La Martillada, the weaver Simeón Alveo prefers bejuco mula (Heteropsis oblongifolia Kunth) for making baskets because he perceives the central fiber as soft to weave; he harvests it when it is "thick as a cable" and observes that this species has the longest pieces (tramos) without branching. Artisans utilize the freshly harvested green fiber of bejuco de tortuga (Anemopaegma orbiculatum (Jacq.) DC.; the seeds resemble a turtle or tortuga) to make a white-colored basket; the fiber stiffens as the basket dries. The weaver uses an odd number of plant fiber pieces for general-use baskets and begins by making the bottom with seven fibers crossing six fibers. Two bellota (Carludovica palmata Ruiz \& Pav.) or birutillo fibers may be woven into this for decoration. These fibers are bent upwards at the edges of the bottom shape, and longer fibers are woven either around its entirety or on four sides. The top rim is made from the entire stem of the vine, including the bark, with other fibers wrapped around it.

Simeón Alveo recognizes two kinds of birutillo (Pleiostachya pruinosa (Regel) K.Schum.): a green (verde) kind which produces green and white fiber and a red (colorao) variety that produces a dark fiber. Artisans prepare the inner fibers of the plant stalk; the green variety produces white fiber from inside the stalk. The weaver shaves regular sized strips of bark with a machete and then shaves the inner plant fiber. Artisans use the fresh fiber strips while still flexible to weave strainers. This birutillo 


\section{Müller-Schwarze - The Arson of a Museum: Ethnography of historical experience and plant fiber use in northern Coclé Province, Panama}

fiber is woven in a specific junco weave (tejido de junco) wherein alternating strips of plant fiber face to the outside and to the inside of the strainer. The strainers are plaited with six or seven strands of fiber. Strainers made from birutillo have bejuco verde (Paragonia sp.) in the opening or "mouth" (boca). The outer covering of the plant stalk is also prepared for a fiber that becomes brown-colored after drying.

Weaving is an innovative and changing art. Individual weavers have preferences among plant materials for their work. Artisans express creative choices in making rims with the same vine that may not be rayado or use bejuco real for borders. Some basket weavers make creative objects, such as a flower holder or a motete with a space for a water bottle. Motetes, churucos, javas, and the nasa can also be made of bejuco colora(d)o (Martinella obovata (Kunth) Bureau \& K.Schum.), a thick vine with a red bark found in heavily wooded areas, or marica. Motetes may also be made from bejuco verde, which La Martillada villagers report can be found in mountains to the north. Bejuco verde does not have a cross in the stem to guide the artisan. Bejuco real $(H$. oblongifolia), a round vine, is said to produce a coveted and fine fiber and is used for durability.

Odorous roots that dangle from the La Martillada waterfall cliffs are locally called a "vine," bejuco dormilón (Anthurium clavigerum Poepp.). The bark of bejuco dormilón removes easily to reveal the inside fibers which are used in weaving. People explain the name dormilón, or "sleepy," in that when the leaves close they "sleep" and one can easily pull the roots down. Villagers say there is a specific gentle pull that releases the roots, but that if one pulls with too much force, the plant doesn't want to wake up. Villagers make a bejuco dormilón collar to cure dogs they have diagnosed with cough.

La Martillada weavers recall other vines that they used in the past, such as the thick parts of two varieties of granadillo. La Martillada artisans remember a vine they call bejuco de estrella, which had a variety for weaving and another variety for medicine; they describe the weaving plant as a star-shaped cross section and a black bark with a red star-shaped flower. Not all vines are useful for basketry; other artisans told me emphatically that bejuco de estrella is not used in their work. The same bellota fiber for hats is also woven into baskets. Simeón Alveo uses thick pieces of the bejuco dormilón, which he peels while it is still green, for making hats. Individual inclinations in weaving likely influence plant preservation.

Weavers care for utilitarian plants in their house yards or harvest these fibers in microhabitats of the surrounding environment (Müller-Schwarze 2006b); they are aware of the locations of and sometimes walk an hour to collect plant fiber resources. Villagers often refer to the collection of "vines" for basketry and other items as a critique of state land titling programs that focus on agricultural lands and therefore do not reflect local harvesting practices (Müller-Schwarze 2015). Artisans harvest vines when radios report that ocean tides are high. Vines, as with other plant materials, are not gathered under the new moon because weavers believe the finished handicraft will fall apart in a short time.

Weaving is not gender-specific knowledge, as there are both women and men artisans. In comparison, Levinsohn (1980) describes Kwazulu basket manufacture with gender in mind; women make baskets. Both genders in La Martillada work with plant fibers, and although men tend to weave baskets and women tend to make hats (MüllerSchwarze 2006b), individual specialization in preparing and weaving plant fibers is more important than gender in determining who makes these items.

\section{Hat manufacture}

Hat weavers sit for hours and days and braid plant fibers into hats with delicate black designs on a white background; "Panama hats" take weeks to make. The weave and plants used in such a hat determine its monetary value and its symbolic value. The cost of hats varies from US $\$ 5$ to over US $\$ 200$, depending on the weave delicacy. Expensive, finely-woven bellota hats are worn to town or on special occasions. Elder men rarely remove their hats; a well-made hat may be their most expensive possession. On rainy days, men cover hats with handmade rubber (caucho) coverings formed in the shape of a hat. Men wear junco (Cyperus sp.) hats for work in the fields and protection from the sun during quotidian rural life; these are a more affordable alternative to the bellota hat. The weaver removes the outer peel (cascara) of junco stalks and uses a needle to pull apart the fiber. Black chonta palm bark fibers are woven into junco hats.

Hats in Coclé are manufactured in a similar way to earlier descriptions (i.e., de Leon in Mason 1988[1904]:494). Weavers collect unfurled leaves of bellota along streambeds. The artisan, often a woman, separates the soft inner part of the unfolded leaves from the hard, green outer edges with a sewing needle. (The unfolding new bellota leaves are boiled for hat fiber, and the stem covering can be woven into baskets just like birutillo fiber.) She then ties these inner leaves into oval bundles and boils them with citrus to enhance whitening. A distinction is made between those specialists who know how to sew hats and those who know how to weave hats. Weavers attach fibers to a metal circle from a "Peruvian" saddle (montura Peruano) that they hang above their seat. The artisan braids an odd number, such as thirteen or fifteen, bellota fibers into a crinaja braid (Figure 5). A crinaja has 26 individual strands when each of the two sides has thirteen. She then delicately sews together these fibers, from the center top of the hat and moving to the brim. Such wo- 


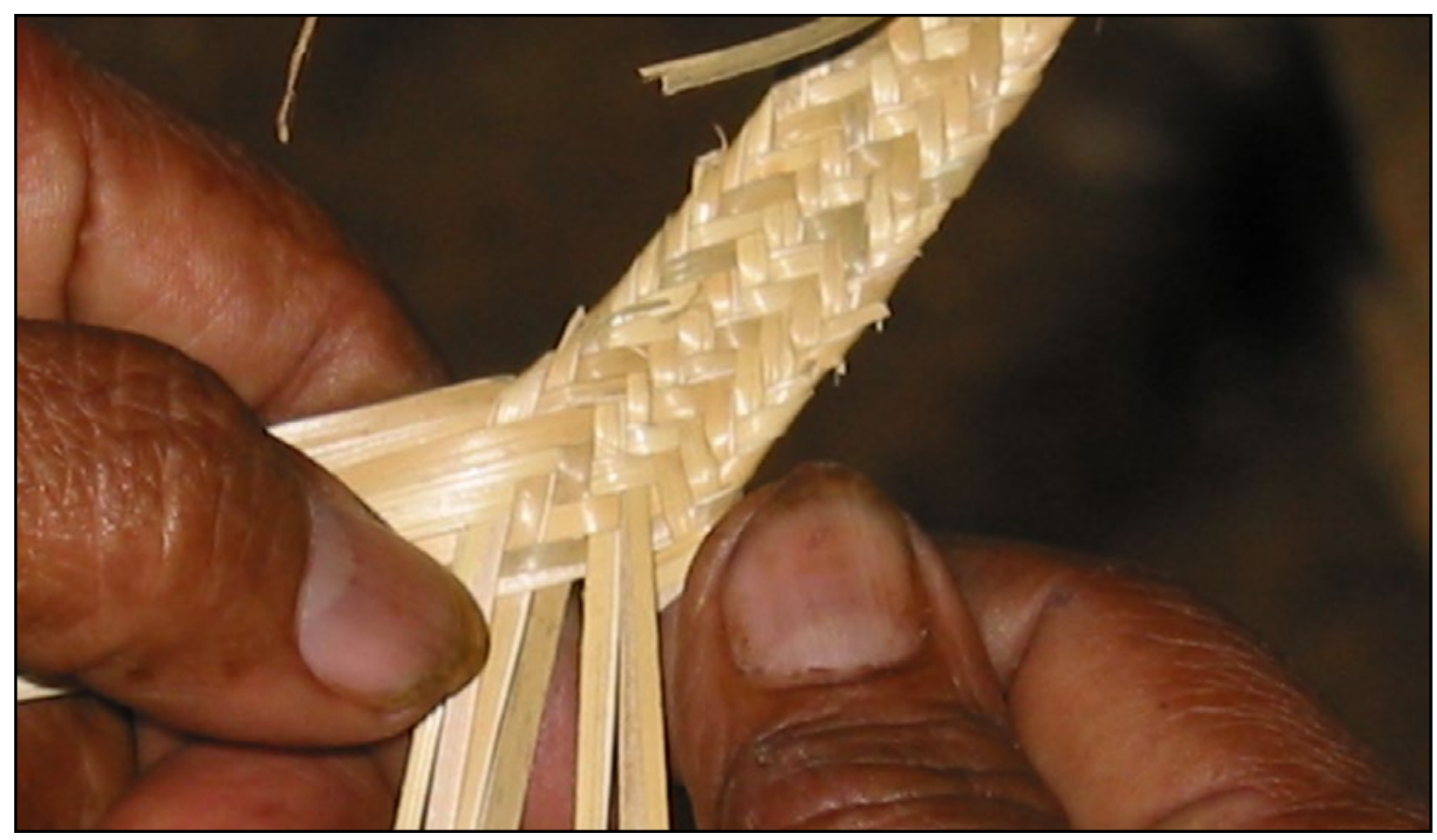

Figure 5. An artisan braids plant fiber into the crinaja, which are then sewn together into the distinctive hats from northern Coclé, Panama.

ven strips (crinaja) are sewn together with store-bought thread on hats made from junco or bellota.

Elders know how to use pita (Aechmea magdalenae (André) André ex Baker) plant fibers to sew the braided or woven strips together into hats. The green outside of the pita plant is scraped off with a spoon, washed like clothes in the river-some artisans leave it out in the dewand eventually it turns white. The fibers are not cooked. Simeón Alveo in La Martillada then rolls the fibers on his upper leg to prepare them for braiding.

Pita fiber is harvested under any moon other than a new moon because that harvested under a new moon is understood to break. It is generally considered better to harvest fibers under a full moon, a practice comparable to Ngäbe people that Lincoln (2004) describes as observing taboos regarding harvesting pita under anything other than a full moon.

People throughout northern Coclé consider rope braided from four crinaja (soga de crinaja) so strong that they use it for fishing line, for the shoulder straps of motete baskets, for horse whips, to tie animals, and to tie the skin onto hollow corotú (Enterolobium schomburgkii (Benth.) Benth.) trunks for musical drums that have been smoothed with chumico. Horse whips made from majagua are considered strong and durable, yet they are sometimes also made from malagueto fibers. Motete shoulder straps are often made from artificial fiber or crinaja made of majagua.

Coclé hats may include a design woven into the white hat with black-colored fibers. Some white fibers are boiled with lemons to retain the white color, while other bellota fibers are boiled with black earth or natural dyes like chisna (Fridericia chica (Bonpl.) L.G.Lohmann) or ojo de vena(d)o (Mucuna mutisiana (Kunth.) DC.) vines (MüllerSchwarze 2006a, 2006b) to color them black. The design (tejido) in the weave of the hat may have one color, zigzag lines, or a black color: this is called the tarco. Cordero Pérez (No date:74) describes as regional the distinct chemical processes employed in Coclé for hat fiber dying.

\section{Other plant fibers}

Quotidian items are manufactured from locally sourced plant materials. Weaving is an important skill. There is much innovation and creativity, and those objects used in daily life change. Change does not imply "loss," but rather demonstrates creativity and adaptability to fluctuating circumstances and the vicissitudes of life (Müller-Schwarze 2006b, 2015). Plant fiber hammocks and rope are used alongside those made from synthetic fibers. Some villages in northern Coclé are connected through a network of trails that people use for foot and horse travel; howev- 


\section{Müller-Schwarze - The Arson of a Museum: Ethnography of historical experience and plant fiber use in northern Coclé Province, Panama}

er, new road cuts have changed realities in specific areas. Plant fiber items associated with horse travel, such as baskets used for transporting items on horseback, are used in areas that have fewer road cuts because horses are necessary for travel along trails.

Cortezo (Apeiba membranacea Spruce ex Benth. or Apeiba tibourbou Aubl.) cambium is soaked in the river during the dry season, then twisted into rope called majagua. Majagua rope is used often and serves to tie together palm frond house roofs; bejuco real, bejuco estrella, bejuco loco, and bejuco verde are also used to tie houses together. Strips of majagua are used without twisting to fasten together house beams. Agriculturalists who harvest the staple crop rice grip the stalks in one hand and then tie the bundle with a majagua rope piece they had around their wrist; this is a measurement called one hand (mano) of rice. Simeón Alveo distinguishes between female cortezo trees which he finds produce a lighter fiber and male cortezo trees that he reports produce a more durable fiber. Cortezo trees grow in abundance in fallows near La Martillada village because agriculturalists have a predilection for leaving them when clearing swiddens.

People now prefer commercial fiber hammocks and claim majagua hammocks do not last as long. Cotton is twisted into cords to make rope (soga), hammocks (hamacas), and bags that men carry. Elders remember that hammocks and rope were often made from malagueto (Xylo- pia frutescens Aubl.) in the past. Two guagará (Manicaria saccifera Gaertn.) palms grow in La Martillada village, and elders recall that the fruit covering (tutulo) of the guagará palm was used as a shoulder bag. In contemporary times, animal feed sacks or the plant fiber bags that are woven by Ngäbe Native Americans and sold between rural areas are used in northern Coclé as bags. People are skilled at transporting almost anything, including food items like eggs, in shoulder bags made from plant fibers.

A basket similar to the motete, but smaller and rounder, is the java. Women in the Indio River region today transport children in java baskets with a majagua or malagueto tumpline and hang the baby in the java on a tree while they work in the fields. Javas are made from bejuco ajo (Bignoniaceae). Elders recall that, before the road was cut to enter La Martillada village, they carried produce in javas on a horse to the provincial capital Penonomé. Two javas tied to a wooden pole on each side of a horse were connected with a rope across the back of the animal. Today, the java has been replaced with reused feed sacks (sackos) to transport merchandise on cars, buses, and horses. In comparison, in Indio River villages, javas are still used in this manner (Figure 6), as horses and canoes are the main means of transport along trails and rivers.

Horse saddles in the mountains contain plant fiber items; padding underneath the saddle is woven from esterilla (Eleocharis elegans (Kunth) Roem. \& Schult.), and the

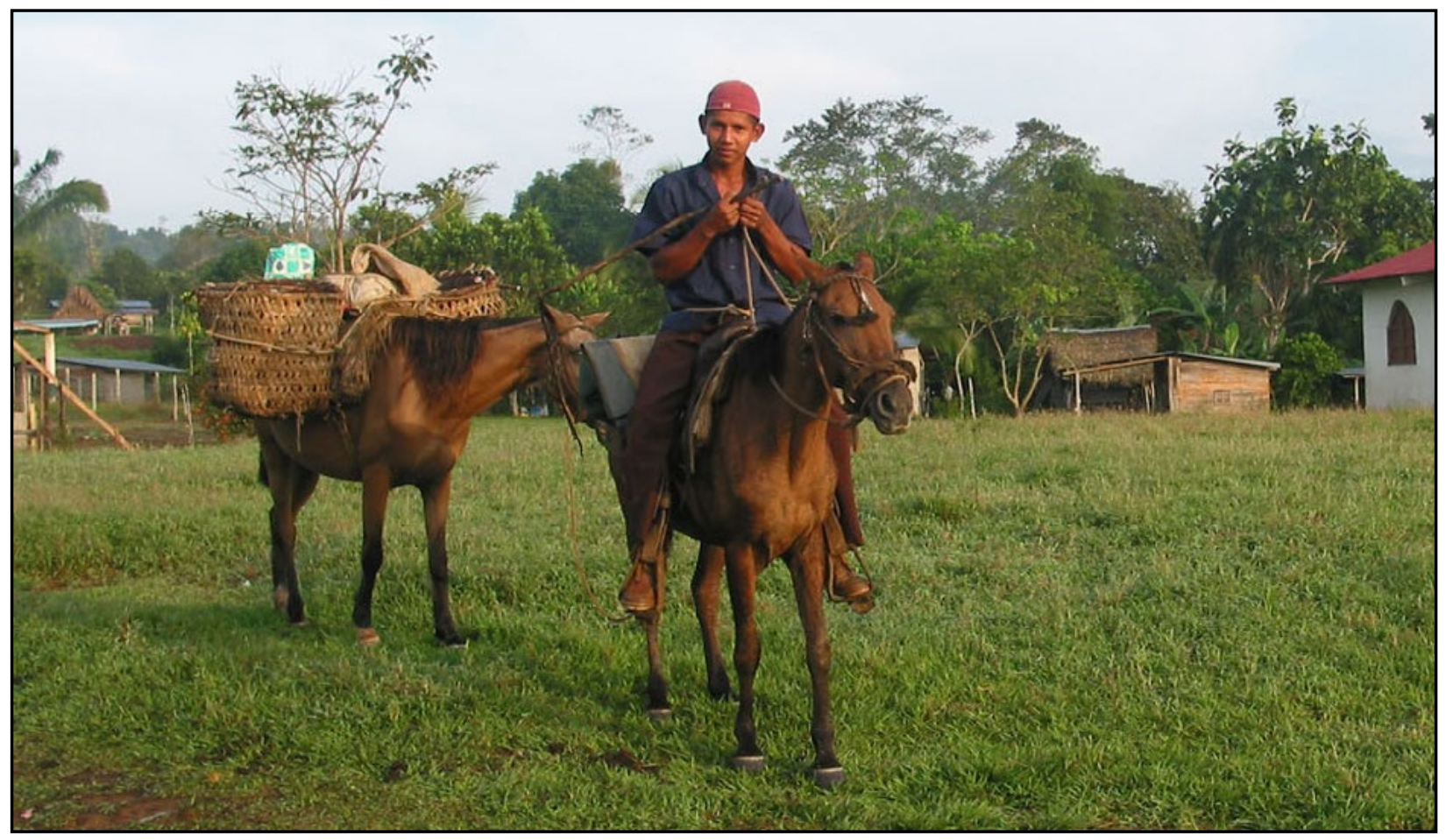

Figure 6. A villager transports items in java baskets attached to a horse saddle. San Cristobal, Coclé, Panama, 2005. 
entire saddle may be covered with a handmade rubber sheet to protect it from rain. People remember other uses for these plants in earlier times. People wove junco into a surface to sleep on. In La Martillada, people remember a plant, locally named cuerón, the leaves of which were used to wrap meat, salt, and other merchandise before plastic bags became widely available. The strings on musical instruments are made from pita fiber. Humans live within the surrounding environment in an intimacy that includes many of the objects of daily life in northern Coclé. Baskets and other woven plant items are just some of the many daily objects made from plants.

Artisans weave plant fibers in La Martillada into utilitarian items for quotidian use. In contrast, many people from the mountains to the north transport and sell plant fiber objects in the Penonomé regional capital market. An increase in tourism along the Pacific coast of Coclé province has provided an opportunity for villagers to sell more handmade plant fiber items. Villagers have adapted by producing hats and baskets in small sizes which are easily carried home by tourists. People have learned to make smaller versions of all the woven items for sale at the annual regional Orange Festival in Churuquita and for sale in the provincial capital Penonomé to tourists. Sometimes the name of the province or the provincial capital is woven into the designs and a small hook is attached to facilitate hanging these items.

Distinct plants are available further north in the mountains from La Martillada because of soil and microhabitat variety. An epiphyte with roots hanging from the forest canopy but locally called a "vine," the bejuco de acla (Bomarea edulis (Tussac) Herb. or Bomarea carderi Mast.) is rarely found near La Martillada. Acla is white inside, with a hard brown bark outside. In contrast, the Coquillo store sold acla hats in May 2010 that Faustino Sánchez had made and covered in varnish, which demonstrates the abundance of the plant in that area. The weaver Faustino Sánchez in Las Marias recognizes two varieties used for weaving: acla ronchosa and acla lisa; he prefers the lisa variety. Acla can be used to make motetes. Artisans report that bejuco real strengthens the edges of hats made from acla. In 2010, the weaver Faustino Sánchez in Las Marias sold a small tourist-sized nasa made of acla for $\$ 1.50$ to a middleman who then took these items to the provincial capital Penonomé. He sold hats and baskets made from bejuco verde in a similar manner. The village of Cerro Miguel is rumored to have a lot of bejuco mimbre (Philodendron sp.) in its vicinity.

Agriculturalists in the northern mountains manufacture wicker furniture from plant materials. Furniture varies with the style of the maker. Such furniture was formerly made for personal use, but now the market for it outside the northern mountains recognizes a specific aesthetic. Long strips of the outer covering of the bellota stalk are woven into panels and nailed onto sangrillo blanco (Cro- ton draco Schltdl. \& Cham.) frames tied together with bejuco chumico (Tetracera volubilis L.) and nails. Chairs are made from slices of matamba (Desmoncus orthacanthos Mart.) bark and bejuco cuatro caras. A chair can be softened with edges of conga palm leaves that are cut to make round the corners that will be under the knees of the person that will sit in the chair. People transport such furniture on horseback or on foot to roads. Small buses (chivas) that transport people to the provincial capital from northern Cocle are often loaded with such furniture, which people from the mountains sell in the Penonomé market and on the side of the Interamerican highway in Penonomé.

The demand for such furniture has affected plant preservation. Common stewardship of plants includes the practice of harvesting the oldest leaves and leaving the center of a plant (gogoyo) to allow it to continue to grow. The competition for sales, however, means that many people have used up their vine resources in the mountains. Gossip reports that people rob vine resources from each other and that plants are so scarce that even bejuco chumico, a less desirable plant, is used for furniture making. However, agriculturalists leave sangrillo blanco in cleared swiddens, and as the seeds fall, they sprout. Some families transplant these small trees. People live within the surrounding environment in daily life; they value plants and make many quotidian objects from plants.

\section{Cucua}

It is in this context that artisans in San Miguel Centro village make cucua dance outfits. Artisans live within the social worlds of northern Coclé and utilize plants understood within local understandings and the context of basketry and weaving, yet also travel to attend seminars and have expressed creativity in cucua dance outfit manufacture. Adaptability and versatility have ensured preservation.

People throughout northern Coclé understand plants to have either hot or cold properties, and utilization of plant fiber sources depends on their classification as hot or cold plants. Varieties such as white, cucua blanco (Poulsenia armata (Miq.) Standl.); red, cucua colorao or sandí (Brosimum sp. or Naucleopsis sp.) which gives an orange-colored cloth; and oreja de puerco (Ficus maxima Mill. or Ficus tonduzii Standl.) are all referred to as cucua. The cucua trees and fibers are considered hot plants, and thus they are understood to keep people warm. The temperature of the plant is understood to pass to the person, and there are many customs surrounding how one acts with regard to perceptions of warm and cool. The color of red cucua is understood to convey heat. Material objects made from such plants have uses understood to keep people "warm:" people make white or colored hammocks which are then painted; bed mattresses; and a child walker (chirigua) made from cucua colorao cloth sewn in a circle of vine and hung from house rafters. Florentino Morán (pers. 


\section{Müller-Schwarze - The Arson of a Museum: Ethnography of historical experience and plant fiber use in northern Coclé Province, Panama}
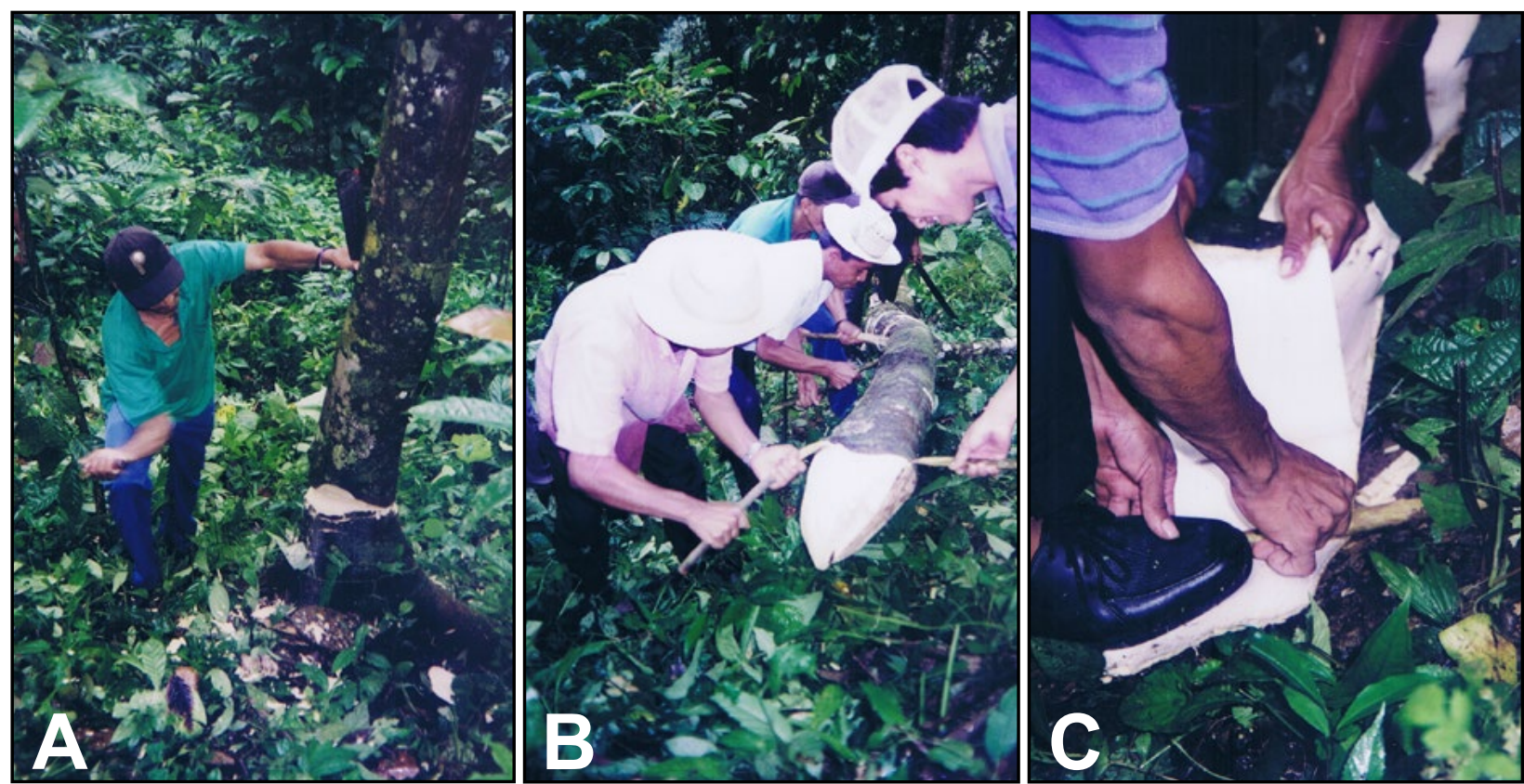

Figure 7. Juan Mandoleno Morán fells a cucua tree with a machete (A), and then Severiano Sánchez, Daniel Morán, and Juan Mandoleno Morán (left to right) remove the outer bark of the tree (B). They then extract the cambium underneath (C). San Miguel Centro, Coclé, Panama, 24 June 2000.

comm., San Miguel Centro, 2005) recalls that cucua colorao was used for clothing and cucua blanco for bedding. There are various other tree sources that artisans manufacture into fiber suitable for cucua purposes, such as manzanilla (Acmella alba (L'Hér.) R.K.Jansen). The artisan Silvestre Ovalle (pers. comm., San Miguel Centro, 2005) prefers each species depending on the circumstances; he remembers the higuerón being useful when he had to make dance outfits for over twenty dancers and he needed a long sleeve in a rush, yet he prefers cucua blanco when he makes a dance outfit.

In San Miguel Centro in 2001, the harvest and elaboration into cloth of these plant materials began with men who selected a tree about six years old, as they observed that saplings produce fibers that are too loose and older trees produce fibers that are too tough for elaboration (Florentino Morán, pers. comm., San Miguel Centro, 2010). The artisans used machetes to fell a tree, then pulled off the dark outer bark and separated the fibrous cambium underneath (Figure 7). They noted that cucua blanco in particular and all saplings have a sap that irritates the skin, so immediately after harvesting, the cambium is rinsed in the river, carried back to the village, and pounded with a grooved stick (meseta) that is made from naranjilla wood (Figure 8). They explained that cucua colorao expands when pounded. They then washed the cambium again and left it to dry in the sun. The cambium pieces of the dance outfit were then sewn together with pita string.

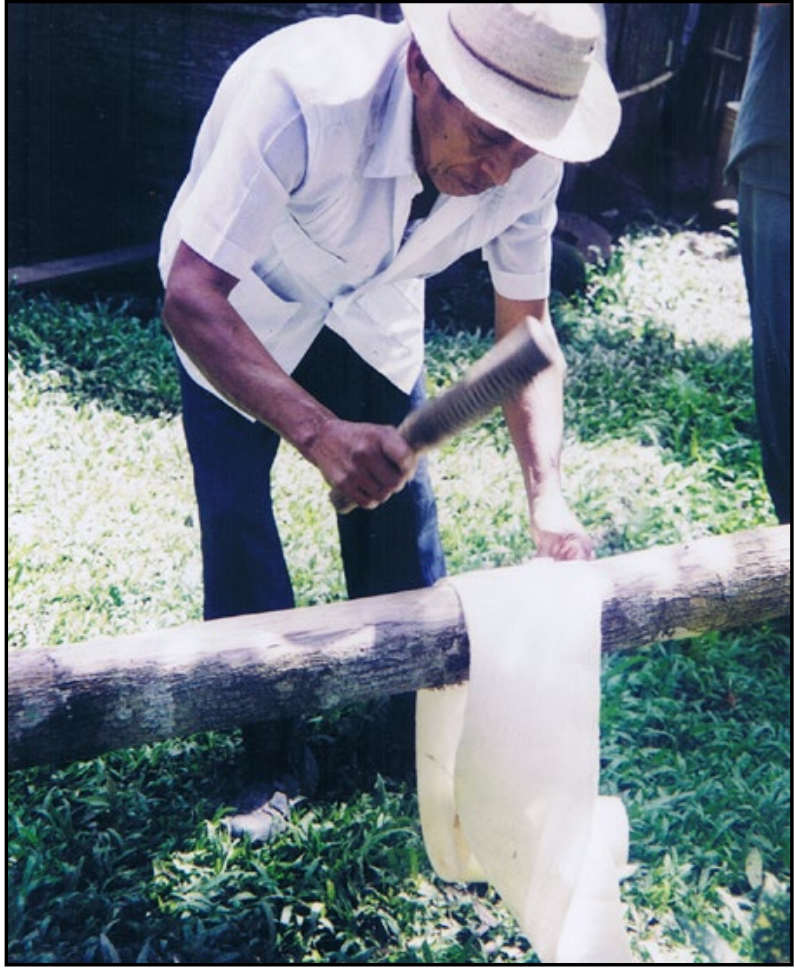

Figure 8. Lucas Sánchez softens the cucua cambium with a tool (mazeta) that is used for the cucua blanco tree variety. A thicker tool without indentations is used when artisans work with the cucua colorao cambium. San Miguel Centro, Coclé, Panama, 24 June 2000. 


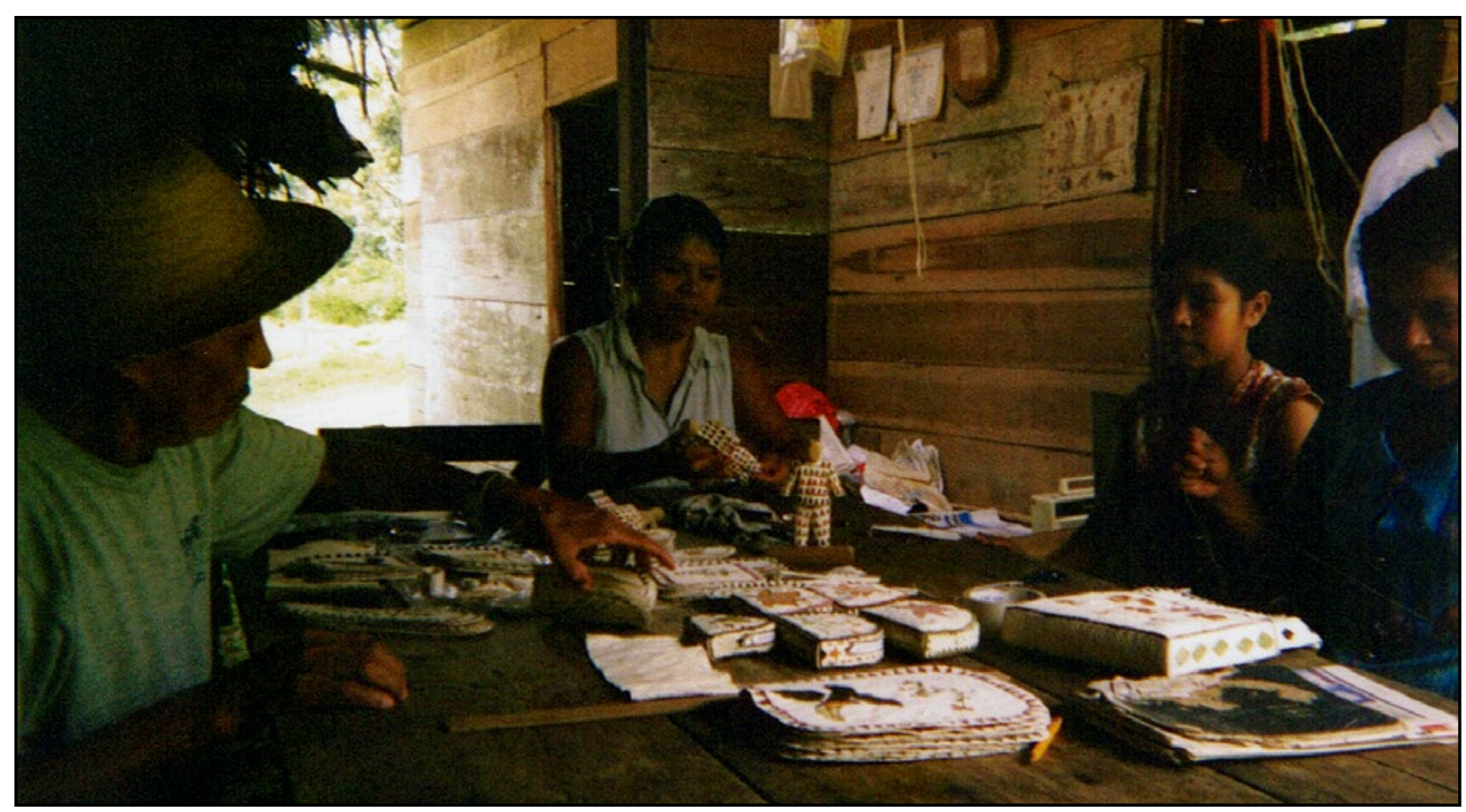

Figure 9. Bacilio Morán, Bacilia Morán, Lucas Sánchez, Anita Riviera, and Miriam Velazquez sit at a table to create artisan items from cucua materials. San Miguel Centro, Coclé, Panama, July 2005.

Masks for the dance outfit are made by stretching painted cucua material over a basket structure, wild pig jaw, and deer antlers. A structure inside the mask-made from either bejuco verde, tortugillo (called bejuco tortuga in La Martillada), or the more desirable and flexible birutillo-supports the bark cambium. The weaving inside the mask is made in motete stitch.

This dance outfit is then decorated with designs made from plant dyes. The cucua maker Florentino Morán (pers. comm., San Miguel Centro, 2010) recalls that the outfits used to be striped and credits his own inspiration while watching leatherworkers to make wooden stamps (marquillas), which artisans now dip into plant dyes to make lines and designs (Figure 9). Artisans cut the stem of caña blanca at an angle to paint outfits (Florentino Morán, pers. comm., San Miguel Centro, 2010). Materials are harvested before but not during a new moon, as any plant material harvested under a new moon is understood to be defective.

Masks and their associated long trains (pañuelos) are covered with detailed images of the local flora and fauna. Artisans credit intuition or a sixth sense for the designs they make. Florentino Morán (pers. comm., San Miguel Centro, 2010) describes his inspiration, "When I worked alone in earlier times, I would be tired and walk far and watch, and when I got home, l'd draw in a notebook and invent the art. My family looks at my notebook for inspiration. And my family has learned to do it; they are continuing it." The images on the pañuelo depict an under-

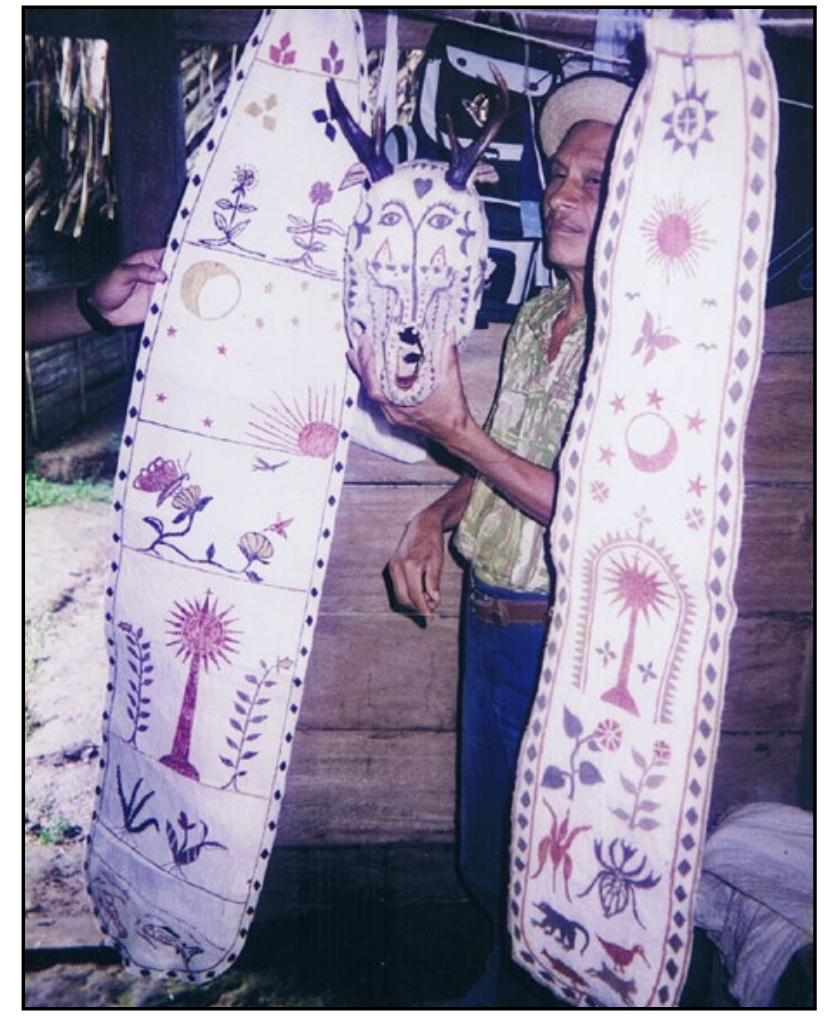

Figure 10. The artistic style changed as villagers began exploring new dye plants and new colors to decorate the cucua dance outfit. Modesto Agraje shows his art, San Miguel Centro, Coclé, Panama, 2010. 


\section{Müller-Schwarze - The Arson of a Museum: Ethnography of historical experience and plant fiber use in northern Coclé Province, Panama}

standing of self in the world, or cosmology. The pañuelo depicts the being (ser), the soul in the world of nature. A circular design in the middle and center of the pañuelo depicts the Eucharist, or Catholic understanding of embodiment of Jesus Christ. Florentino Morán describes the pañuelo as expressing the universe, air, the faith one has and one's belonging in the Catholic Church in the form of the Eucharist, and below this, trees, animals, and fish. Similarly, Modesto Agraje (pers. comm., San Miguel Centro, 2010) paints with plant dyes three panels of the panuelo to show the sky, person, and the earth or underworld (Figure 10). He explains that these three areas depict animals of the air (such as birds or butterflies); symbols of the church (a cross or the Eucharist); and symbols of the earth (such as animals of the earth). He also explains the images of the sun, moon, and Eucharist, as well as the pañuelo itself, as "sacred" and the symbolism as "the tradition is alive and all the animals are here." Florentino Morán (pers. comm., San Miguel Centro, 2010) recalls learning to dye images of the sun, the moon in its current phase, and the Eucharist (sacramento) on the pañuelo, but could not comment on any further meaning.

There has been much innovation recently in plant dyes; artisans have learned much new information through attending seminars and conversing with colleagues from other rural areas of Panama. In 2001, artisans decorat-

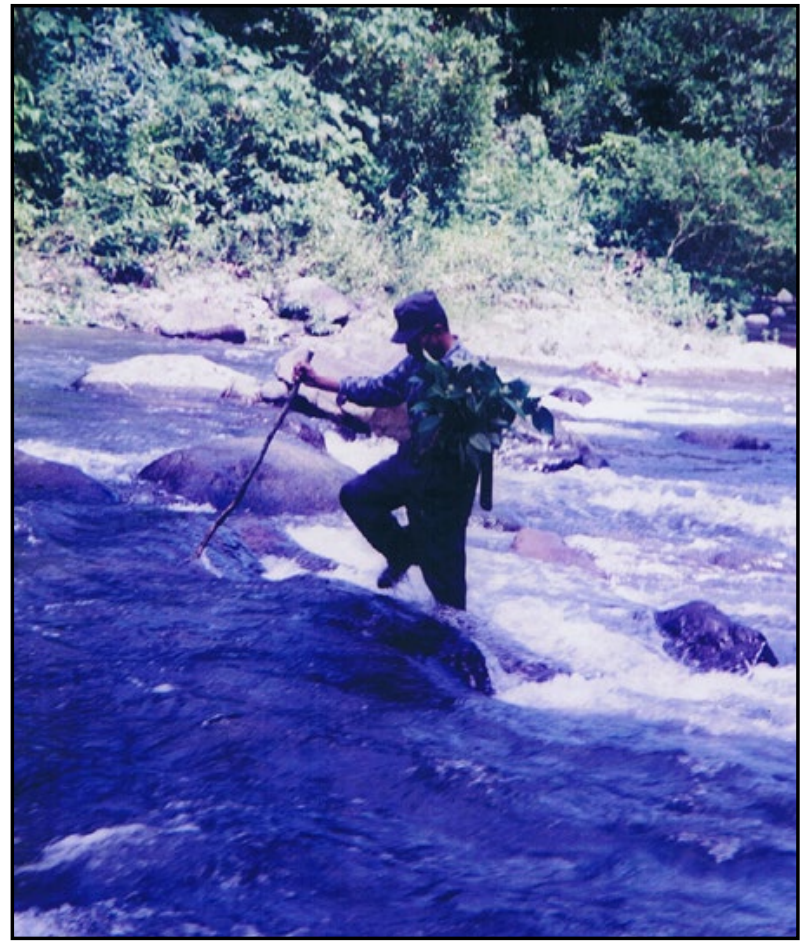

Figure 11. Paulino Morán carries guaymí leaves across the San Miguel River. San Miguel Centro, Coclé, Panama, 24 June 2000. ed the cucua material with three colors and pounded the leaves of ojo de venao in a mortar and pestle to make black dye. They applied guaymí (Morinda citrifolia L.) for red colors (Figures 11, 12) (interestingly, the name of this plant is the same as an earlier name for Ngäbe Native Americans). Until recently, only these two dyes were used for red and black and were mixed to make brown or yellow. Interest from outsiders has resulted in invitations for artisans to attend seminars about dye plants. Modesto Morán recalls a seminar with a Peace Corps Volunteer whereat he learned that added lemon juice changes the jagua dye color. Modesto Morán created dyes in 2005 from the plants yuquilla or yuquita (Curcuma sp.) for a yellow cadmium; jagua roja (Genipa americana L.) for a reddish purple; ojo de venao for black; and ojo de gallo (Melastomataceae) for dark green. Florentino Morán listened to explanations about plant dyes at free seminars at the Atlapa Artisans Fair in Panama City and learned that Emberá Native Americans use jagua negra to make a black dye; he tried it and also found that jagua morado makes a purple dye. Subsequently, people experimented with adding different substances to the dyes, and now a rainbow of colors are produced and used. Yuquilla dye is combined with red or black to make a darker yellow. People have, however, always been creative; Asunción "Junito" Alveo in La Martillada recalled in 2005 that people used to dye majagua string yellow with yuquilla dye,

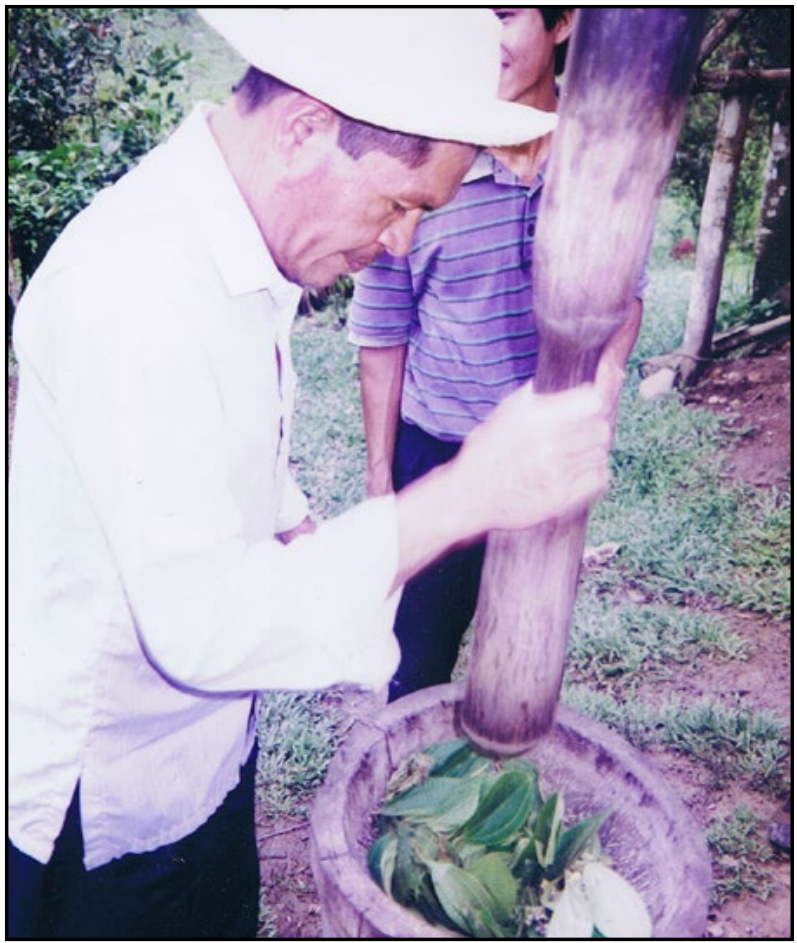

Figure 12. Herbacio Morán crushes guaymí leaves in a large mortar and pestle. San Miguel Centro, Coclé, Panama, 24 June 2000. 
black with chisna, and blue with a store-bought dye he called añil and would weave colored bags from this string.

Several Peace Corps volunteers encouraged knowledge of business techniques and cultivated contacts for dance performances outside the village. A Peace Corps volunteer, Alon Terry, initiated projects such as the making of souvenir dolls and nurtured contacts with companies such as Gran Morrison and tourist markets to sell them. Such opportunities have resulted in more detailed and creative applications of plant dyes. Cucua items stained with plant dyes in 2005 included camera cases, cell phone holders, and multi-colored depictions of karate fighters and cartoon characters to adorn houses. At Atlapa, Modesto Agraje (pers. comm., San Miguel Centro, 2010) compared similar cloth made by Native Americans from the Darien and notes that their cloth still had a lot of resin because of a short boiling time, with results more yellow instead of white. He also saw people from Nicaragua and Honduras with elaborated cloth (tela) at Atlapa and notes that their bark (corteza) looks the same, but they use artificial paint. Creative ideas are not contained in one geographical location.

\section{Dances in social and historical context}

Preservation of cucua practices reflects the social location of each artisan. Each dance ensemble in San Miguel Centro contains named positions with specific duties of performance and management that signify the individual's social location within the dance performance and within the village (Florentino Morán, pers. comm.). There are three main devils (the Diablo Mayor, Capitán, and El Dirigente/Teniente) in a dance ensemble. These three not only dance but also speak during performances. The Diablo Mayor has management responsibilities such as initiating and cultivating contacts with people outside northern Coclé. Modesto Agraje (pers. comm., San Miguel Centro, 2010) explains that the Diablo Mayor keeps the devils in order, trains his followers, and commits to this position for a long time; the Capitán and what he terms the Teniente organize the line of dancers; and he explains that the other devils in the performance ensemble don't have named positions. Villagers recounted in informal discussions that the social positioning of the Diablo Mayor, as director of his dance troupe and teacher, has eroded with the emphasis on plant preservation and reforestation by outsiders such as school teachers, NGOs, and others.

The Capitán and Teniente flank the Diablo Mayor during a show. The number of devils, which may be fifteen or more, depends on the payment for the performance. The Diablo Mayor dances out and around the other devils, one time on each side, and then speaks a contextual poetic verse (copla) between each until he has spoken three coplas. In comparison, a depiction of Los Santos dance (in $\mathrm{La}$ Prensa 1985) describes the same two-line formation in space, and then the basic dance steps: right, left, right, right, with a right raised knee hop. The dancer repeats the same on the other side, and at the completion of each step cycle yells "ju-a." Florentino Morán (pers. comm., San Miguel Centro, 2010) recalls that the devils (diablicos) would use a staff (garotillo) — made from a strong wood such as naranjillo (Swartzia simplex (Sw.) Spreng.) or cacique - to scare people and to move through a crowd. The musical instruments that accompany cucua dancers are also made from plant materials. Artisans hollow sigua (Nectandra globosa (Aubl.) Mez) tree trunks to make the bodies of the drum and the violin.

The recited verses refer to the power of the different characters and the amazing feats they have done and ask God for protection for the coming year. Most annotations of cucua and versions I collected have four verses. Most begin with "I am the Main Devil, and I come from the other side" (Yo soy el Diablo Mayor, vengo del otro lao), and subsequent verses contain six to eight syllables per line, four lines in a verse, and every other line rhymes.

Modesto Agraje (pers. comm., San Miguel Centro, 2010) explains that specific redondillas for Corpus Christi refer to religion and that couplets for Carnival are called redondillas de paranda. For example, "Soy el Diablo Mayor, y vengo del otro la'o. Aunque todos no conozco, con todos tengo amistad" or "Yo soy el Diablo Mayor, vengo de por allá, a pedirle a Don Pascual, un trago de refina'o." (Don Pascual refers to the host of the festival.) Silvestre Ovalle (pers. comm., San Miguel Centro, 2010) notes that to compose a redondilla is an art form; he includes the name of the place they are visiting in his verses when he performs. (In comparison, Isleños, descendants of immigrants from the Canary Islands in southern Louisiana, sing décimas that relate incidents and characters from St. Bernard Parish. The Canary Islands Descendants Association in southern Louisiana has printed pamphlets titled "The Significance of the Décima" that quote the scholar Samuel G. Armistead who identified the Isleño four-verse quatrain as distinct from the ten-verse stanza sung in the Canary Islands.)

Narratives about cucua situate the dance in historical experience. People throughout northern Coclé knew how to prepare the dance outfits, yet would gather in San Miguel Centro on Corpus Christi in order to travel to Penonomé and perform (pers. comm., San Miguel Centro, 2010). Mass was held in the Penonomé church on the Wednesday before Corpus Christi Thursday (sometimes spelled "Corpu Christi" reflecting the Coclé dialect which often doesn't pronounce /s/). Florentino Morán (pers. comm., San Miguel Centro, 2010) recalls that, "on Wednesday [the devils] would arrive [from other communities] in the morning and go to the Penonomé church, entered to listen to the mass, and when the mass ended, 'ju-a' and go out onto the street. Passing the houses, streets; danc- 


\section{Müller-Schwarze - The Arson of a Museum: Ethnography of historical experience and plant fiber use in northern Coclé Province, Panama}

ing. People who danced along gave us drinks." Florentino Morán credits three directors for teaching him redondillas: Leonardo Gonzalez from San Miguel Centro was the Diablo Mayor; Pedro Velasquez from San Pedro was the Diablo Teniente; and Juan Paulino Alabaca from Indio River was the Capitán. Florentino Morán began dancing in 1949 and notes the ensemble was no longer going to Penonomé then. It seems this practice was revitalized.

Modesto Agraje (pers. comm., San Miguel Centro, 2010) recalls only one ensemble (with dancers from communities such as Alto Uracillo, Vallecito, Chiguirí Arriba, San Pedro, Boca de las Minas, and Chiguirí Centro) existed when he started dancing in 1967 and that they would travel to Penonomé together to perform the cucua for the annual festivals of Corpus Christi, village foundation, and Carnival, and he claims there is a photo of this dance ensemble displayed in the Penonomé Municipal Building. Modesto Agraje maintains that the dance ensemble stopped going to Penonomé in 1997 or 1998 because of transportation expenses. He reflects that the dance was preserved in San Miguel Centro as it was the home community of the Diablo Mayor, Leonardo González, who then passed the position on to Florentino Morán. Modesto Agraje recalls that he became Diablo Mayor in 1995 when the previous one, Humberto Morán, became ill.

Cucua dancers continue to dance in San Miguel Centro and depict a meeting between an angel and the devil during the annual patron saint festival on September 29 , the occurrence of which depends on vicissitudes in the organization of the community. Florentino Morán (pers. comm., San Miguel Centro, 2005) describes the dance: "In earlier times, the cucua dance of the devils represented a confrontation between good and evil with the figure of the masks with antlers (cachico) and teeth (gosico) that represent evil. The devil confronts Saint Michael in the dance." The person portraying Saint Michael wore blue and red cloth, carried a sword and a helmet, and stood in front of the church (Florentino Morán, pers. comm., San Miguel Centro, 2005). The cucua devil dancers would exit the house where they had gotten dressed and approach the character of Saint Michael, calling out "ju-a." In recollections of the drama in Penonomé (i.e., No author 2003b, Tejeira No date), Saint Michael is depicted by a girl dressed in white and a crown of flowers and is said to represent a pure soul. The actors exchange poetic words (redondillas). The angel may strike the devils with the sword in the theatrical presentation. Purity scares the Diablo Mayor, and the devil dancers scatter. The dance depicts in theatrical form a soul in dispute between the devil and the archangel.

\section{Preservation of cucua and the arson of a museum}

Cucua practices express the balance between cosmological forces. Dancers and artisans navigate a social terrain that includes tensions within the village and among outsiders who are sometimes too enthusiastic about the cultural resources cucua practices seem to offer. Attention from outside the village regarding cucua is couched in narratives about preservation, yet is perceived locally as desire to possess and contain cucua. Individuals and agencies from outside the community have focused on plant preservation and sometimes overlook the social structures within dance ensembles. This heightened tensions in the village to such an extent that it resulted in the alleged arson of a museum. Clifford (1997) describes museums as zones of contact comparable to the trading posts of early colonial days. Items in museums have different meanings for various perspectives. It is interesting to understand and document how dancers and artisans themselves narrate preservation of cucua and situate these practices within their own historical experiences and dignity.

In the first decade of the millennium, there were two main artisan and performance ensembles in San Miguel Centro. The Morán family has long been established with their Grupo Folclórico del Cucua. The Diablo Mayor among the dancers, Florentino Morán asserts that he has performed in this role since 1947. Florentino Morán recalls being asked to dance for a longer period of time at a 1974 performance in Penonomé and claims the dancers then incorporated other "folkloric" dances beyond the Dance of the Devil, such as the fachenda which is danced by one devil, the chogoro, and the cumbia in their performances outside of the village. Dances were altered to accommodate performances in creative ways. He recalls dancing with the ensemble at a 1987 silver anniversary celebration at the Penonomé church, when the dance troupe had eleven couples. The dancers manufactured the outfits and crafts, presented the dances, and continue to do so.

Silvestre Ovalle (pers. comm., San Miguel Centro, 2005) is the Diablo Mayor of another dance and artisan ensemble in San Miguel Centro and credits the preservation to individuals; he recalls that his father and a teacher from the school, Valentín Uvarto, revitalized interest by teaching the cucua and fachenda dances in the 1980s, when the practices had almost ceased. In 2005, Silvestre Ovalle became director of a children's ensemble, the Conjunto Folclórico Escuela Candelario Ovalle, that had previously been tied to a San Miguel Centro school. Villagers have interpreted school teachers' management of children's dance ensembles as disregard for the existing social structure. Florentino Morán notes that the community suspected a teacher had been stealing funds and was not perceived to share videos of the performances with the village.

Artisans from San Miguel Centro travel each August to the large Atlapa Artisans' Fair in Panama City to sell their wares. Florentino Morán remembers attending since the 1990s, and he credits Ilsedith F. de Quezada for coming to the community to work on a reforestation project and for inviting the dance ensemble to perform at Atlapa. Silves- 
tre Ovalle (pers. comm., San Miguel Centro, 2010) recalls that his dancers were subsequently invited to Atlapa after his son brought a children's performance ensemble to Río Hato to participate in the 1980s political Macho de Monte rallies orchestrated by the Omar Torrijos presidency. Silvestre Ovalle (pers. comm., 2005) recollects that their first performance at Atlapa in 1999 had no music, and he says he has accompanied the children's performance ensemble as a musician ever since. This is corroborated in Conte Guardia (1963-1964), who interviewed an elder man from Sagrejá who had performed as a cucua devil dancer; he remembered not having instruments, but rather the only musical accompaniment to the dance was the "ju-a" voice and the beating of sticks on the ground. Florentino Morán (pers. comm., San Miguel Centro, 2010) claims that the other dance troupe only recently invented hitting the ground with a staff, a comment which may portray the recent rivalry between the ensembles.

Villagers remember "Diana Chiarí" as an outsider who helped preserve the cucua dance. Florentino Morán relates that Diana walked to San Miguel Centro in 1972 and sought him out after she had seen his name on a dance outfit. He credits her with being the first person from "outside" the community to visit and express interest in cucua, and he recalls that she gave the Atlapa Convention Center in Panama City a cucua outfit that is prominently displayed inside the urban building. This is corroborated in a newspaper article commemorating Diana Julia Chiarí de Gruber, a folklorist and professor of art, for promoting recognition and preservation of Panamanian folk arts (No author 2003a). She learned how to make cucua, and four cucua tapestries by her decorate the Atlapa convention center (No author 2003a).

Florentino Morán describes the division of the dancers into two performance troupes as a result of villagers and regional outsiders vying for leadership positions among dancers. He recalls as difficult the collaboration with the National Institute of Culture (Instituto Nacional de Cultura, INAC) — which had invited cucua dancers to participate in folkloric spectacles in the Panama City national theater-because he felt they wanted to run the dance troupe (querían mandar). Silvestre Ovalle recalls waiting months to get paid for a performance at the Panamanian national assembly and how the community did not understand the bureaucratic delay, accused him of corruption, and removed him as Diablo Mayor because of these perceptions.

Interestingly, Silvestre Ovalle recalls a Radio Veraguas $C D$ recording that enabled a large geographic distribution which incited interest from the Netherlands. The Netherlands Committee of the United Nations for Nature started a reforestation program in San Miguel Centro for an endangered species of cucua tree and supported a project in the village through the Panamanian NGO called CECA (Circle of Applied Sciences) (Quezada 2003a, 2003b).
They worked with San Miguel Centro villagers to build a community center, a cucua museum, and a reforestation project (Quezada 2003a, 2003b). Silvestre Ovalle credits Renee Changmarín, a Panamanian biologist, for bringing an NGO to the village and initiating a reforestation project, yet notes that the reforestation project focused on cucua blanco and not the other species artisans utilize. Florentino Morán (pers. comm., San Miguel Centro, 2010) questions the practicality of monoculture reforestation, as trees develop many branches which impede the uniformity of the cloth (tela) for artisan purposes. The Morán family notes that they take care of other plants, such as pita, relevant to the dance. Such narratives reflect the dignity and self-determination in local preservation efforts.

By 2005, a cultural center, touted as a museum outside the community and as a workshop inside, had been built, and San Miguel Centro village as a group was given a generator for the first cucua festival. By 2010, Silvestre Ovalle (pers. comm., 2005) had changed the name of his ensemble to Grupo Cultural Ecológico and recalls working closely with the cultural center. The "museum" included a building where artisans were asked to give presentations to outsiders and a monoculture area planted solely with cucua blanco. Displays inside informed about artisan techniques and the cucua blanco tree and its biology, means of reproduction, and reforestation. However, such generosity from outside the community flamed already existing differences among performers and artisans.

Competition and animosity increased between the dance ensembles and solidified identification as separate "groups." Artisans guarded with secrecy dye knowledge and painting styles. Villagers remarked in 2005 that competition for plant resources had intensified and sometimes resulted in the elimination of local plant sources by rival dancers. One ensemble accused the other of not planting the tree seedlings funded in reforestation plans. This increased opportunities for people from other villages to sell cucua plant materials to San Miguel Centro. Modesto Agraje (pers. comm., San Miguel Centro, 2010) became Diablo Mayor of a dance ensemble, La Danza de los Cucua de los Adultos, that had split off from existing performance assemblies by 2010. Each dance ensemble emphasized its claims to authenticity.

Narratives in the village concur that intervention from the outside disrupted the tranquility and cooperation within the community. The cucua festival has been indefinitely postponed. Villagers commented in informal discussions that the festival was really for outsiders, as they themselves repeatedly see dancers practicing in open grassy areas. The museum structure burned, and villagers maintain that it was arson in culmination of long standing disputes. The narrative of arson reflects discomfort with outsider intervention. The San Miguel Centro museum is now a memory. Many villagers concur that cooperation has been restored in the village in the years since. 


\section{Müller-Schwarze - The Arson of a Museum: Ethnography of historical experience and plant fiber use in northern Coclé Province, Panama}

\section{Discussion}

Activities related to the preservation of (plant) knowledge happen within intersubjectivity between perspectives. Examination of the various discourses surrounding plant preservation reveals the complexities. Data about plant knowledge is found in discourses beyond the conversations artisans have in northern Coclé and at the Atlapa Convention Center. Scholars emphasize data about plant use as evidence of continuous indigenous occupation, and ethnohistorical research methods show both chronological associations and versatility in the use of particular plant species. Scholarly narratives tend to ascribe Native American identification to area residents, yet a study of local understandings reveals that identification as cholo correlates with plant fiber hat use (Müller-Schwarze 2008). Panamanian media narratives stress a historical narrative for the nation-state. However, artisans and area residents are interested in the functions of what they make. People dependent on the surrounding natural environment adapt their knowledge to current needs as historical contexts change. In comparison, Davis (1996) suggests that the colonial encounter forced indigenous Amazonian people to invent more medicinal uses for plants. Political land rights based on "indigenous identity" require people to remain unchanged and exhibit the same cultural traits that were once recognized or rejected (MüllerSchwarze 2015). However, ethnobotanical knowledge, like that deemed traditional in other contexts, remains in use over time precisely because it is flexible and needed for survival (sensu Honko 1995). It is in the interactions between these discourses that plant conservation practices are enacted. Moreover, it becomes important to see plant preservation contextualized in human conversations in the ethnography of historical experience.

\section{Scholarly narratives of archaeology and continuity}

Scholarly narratives about plant use in archaeological evidence emphasize continuity. In the nearby Sitio Conte archaeological site, "bark," probably Ficus sp., was used for grave covers and cotton for "painted cloth" (Cooke \& Ranere 1992:286). Fredrik Johnson (in Lothrop 1937:108112) interprets impressions on clay and copper in the archaeological site as bark cloth, baskets, and weaving and interprets connection between ancients and modern Ngäbe (Guaymí) people. The early Spanish chronicler Oviedo (in Torres de Araúz 1992:44, No date) describes the type of woven hammock people had as indicating their social rank and describes women who wore floor-length naguas of "bark cloth" as higher ranked, with those who wore knee-length ones having lower rank. The Spanish chronicler Adrian de Ufeldre (in Casimir de Brizuela 1971) describes bereaved who dressed a corpse in a funeral dress (pampanilla) of tree bark in the western isthmus. De la Rocha (in Villareal 1992:14) mentions, in the seventeenth century, what he calls bark cloth clothing. Encoun- tered people in the western isthmus recognized a specialist who had the job of painting bodies of others, especially faces, with motifs like human figures, four-legged animals, birds, and trees (Wafer in Casimir de Brizuela 1971).

Discourse about plant knowledge is located in practices that reflect and encourage identification as indigenous. Evidence from archival and ethnohistorical sources supports the understanding that people in northern Coclé today continue to exhibit a heritage from indigenous populations. The direct historical method links historical people with archaeological sites and cultures. Workshops for Coclé artisans have included visits to the Penonomé Museum and the archaeological site of Sitio Conte, wherein participants were encouraged to observe the paintings and designs called "characteristic of central Panama" (Museo de Penonomé 1995:4).

Linguistic evidence related to plant use can also be interpreted within scholarly narratives of indigenous continuity. Romoli (1987:150) writes that the Spanish chronicler Oviedo described a covered basket called hava among people he encountered in the isthmus, and when two havas were placed one inside the other, they were sealed with bijao leaves. The illustration Romoli has cited from Fernández de Oviedo y Valdés (1478-1557) actually shows a round basket carried on a pole. Bijao (Calathea panamensis Rowlee ex. Standl. or Calathea marantifolia Standl.) leaves are used today for similar purposes in northern Coclé (Müller-Schwarze 2006b). The Spanish chronicler Oviedo (in Romoli 1987:73) lists the words hico or hyco as meaning hammock rope. Miranda de Cabal (1974:112) reports the word quisí as the Dorasque word used for the fiber for making chacaras; the fiber would today be referred to as pita. (Miranda de Cabal (1974) describes Dorasque people that lived in the western isthmian highlands as "extinct" at the Spanish arrival due to fighting with people identified as Mosquitoe.)

A review of scholarly sources indicates that the common name for the plant acla also signals antiquity. Romoli (1987) compares similar words from current isthmian indigenous languages and ancient root languages. (Romoli [1987:81] compares what she classifies as the Cuna kala or naimali e kal [meaning bone or tibia, canillas de hombre]; the Cuna word akla, which means repisa, masa, or desvan; and in Chocó akare, which means "below.") In a table of comparison between the ancient "Cueva" vocabulary used in various conqueror texts, Romoli (1987:81) lists "Acla" as "canillas de hombre" as Acra or Acla in Cueva language and as the place of a crucial battle between indigenous; and in Chibcha, "bone" is said as quine or quene or muyscquyne; in Arawak, arka means "to fight." Durán (2003) describes that prehistoric caciques, or chiefs, in the central isthmus took the names of plants and animals. Romoli (1987:59) lists Acra and Ataracherubi, with variants of Acre and Acla or Taracherubi, as the cacique of the sector southeast of Cueva. Aguilar 
(1963:75) locates Acla in Calidonia Bay as an indigenous ethnicity in the sixteenth century. Romoli $(1987: 33,59,70)$ describes the word as a toponym and documents Acla as a place located on the isthmian Atlantic coast in 1525. The Spanish conquistador Pedrarias formed a settlement at Aclá or Ákla, which was later abandoned (Howe 1974:11, 17). Castillero Calvo (1967:38) notes that "Acla" was the name of a plantation (reducción) formed after the Spanish kingdom in 1551 and 1552 recognized the freedom of the native population. Castillero Calvo (1967:67) documents a colonial gold mine on the Pacific coast called "Acla." The cultural use of plants can be interpreted to understand historical continuity.

\section{Plant knowledge in historical context}

Continuities need to be understood in the details of creativity and history; rural people are not located outside of time in an unchanging list of plant uses and basket manufacture. Rather, people remember historical circumstances that influenced and changed plant use. Corroboration of oral history with written sources demonstrates the versatility and creativity evidenced in northern Coclé plant use.

The interaction with the Catholic Church hierarchy encouraged the preservation of plant knowledge for specific crafts. Franciscans, the missionaries who made the earliest contact with people in northern Coclé, encouraged artisan education in hammock, hat, and rope making (Conte Porras 1997:65). Conte Porras (1963, 1997:68, 1998, 1999) sees hat manufacture as something the population of northern Coclé, whom he calls cholos, have done for generations. Lincoln (2004) writes that Central and South American indigenous people have been cultivating pita plants for centuries, and cites the anthropologist Claude Lèvi-Strauss for evidence.

Knowledge about plant use helped people survive the injustices and expectations on Spanish plantations in the colonial era. Castillero Calvo $(1967: 115,117)$ describes Spanish colonial state tribute requirements in the central isthmus on reducciones for widows and single women as a half-pound of pita string (pita hilado). Castillero Calvo (1967:122) describes Indians on reducciones who were able to abandon such concepts about production and return to a subsistence way of life because they gained access to European goods by exchanging artisan goods (artesanía).

According to Suárez (1997:58), people he terms Indians sold pita in Penonomé in the 1700s. Camargo Ríos (2002) interprets the contact that happened during religious festivals in Penonomé as the seed of interdependent trade and identifies three zones of exchange activity in the region, with people nearest to Penonomé trading more frequently. In this time period, Humboldt (in Cordero Pérez No date:73) describes dye being extracted from
Fridericia chica. Penonomé townspeople utilized indigenous plant knowledge in production when they participated in international trade, as documented in 1735, and sent hammocks, nets, wooden trays, rope, and palm-leaf brooms per ship to Lima, Perú (Durán 2003, Rodríguez 1998). Trade ties between Panama and South America included the exchange of hats and hammocks (Figueroa Navarro 1982:41). Such travel routes reflected indigenous knowledge of ancient shipping routes (sensu Lothrop No date).

Araúz (2002) describes 1800s Panama City as dependent on rural imports and cites an 1817 document that records how people from the countryside regularly traveled to the city market to sell products like rice, corn, beans, plantains, livestock, cotton weavings, pita, hammocks, batea trays, and brooms. In the 1800 s, pita was manufactured into goods that were traded to Penonomé and then to Lima, Peru (Camargo Ríos 2002:117). The administration of the Gran Colombian colonel Anselmo Pinedo opened trade schools, such as the hat making school in Penonomé (Figueroa Navarro 1982:226). By the mid-1800s, the Penonomé parochial opened a school to teach hat sewing with a fiber called jipijapa (Quiros 1981:72). The teacher Francisco Lara from Ecuador taught hat making and the use of bellota in the Central School for Hatmaking in Penonomé (Camargo Ríos 2002:126).

Rosas and Ureña (1988) seek an origin point for the cucua dance, which they place between 1824 and 1940, when missionaries entered mountainous Coclé. This makes one wonder as to whether it was in this time period that these missionaries created more documentation about the dance and created interest outside the area. Contemporary documents depict plant fiber use in the area. The botanist Henri Pittier (in Heckadon-Moreno 1996) describes the central isthmian uses of the cuascua or namagua tree for cloth, sails for canoes, clothing, and bed mattresses (petates) in 1911. Nordenskiöld in 1927 (in Villareal 1992:42) documents Bogotá Indians dressed in cloth bark on the Rio Calovébora. Wafer (1960:99) describes majagua fiber use. The travel writer Verrill (1928) describes, "the Cocle [sic] Indians are the most highly civilized of all Panamanian tribes, despite the fact that for years they fought relentlessly against Spain and managed to hold their own at that. Today, they have forgotten their own tongue and live in a far more civilized manner than their Panamanian neighbors ... Once a year they don weird dance costumes of bark cloth with grotesque masks fitted with horns and jaws and the teeth of wild animals, and take part in the 'Kukwa' or devil dance." Biesanz and Biesanz (1955) have photographs that depict area residents wearing large woven baskets on their backs.

Florentino Morán (pers. comm., San Miguel Centro) recalls dance ensembles in both Coclé and Veraguas provinces, but notes that only in Coclé was cucua preserved. This is confirmed by Modesto Agraje (pers. comm., San Miguel 


\section{Müller-Schwarze - The Arson of a Museum: Ethnography of historical experience and plant fiber use in northern Coclé Province, Panama}

Centro, 2010). Today, people in Veraguas province recognized as Ngäbe continue to make similar cloth, yet are not known for an associated dance. It is likely that people in the entire region made cloth from tree cambium. Oral history relates that the elaboration of tree cambium into an outfit can be understood within the framework of precolonial customs of clothes made from tree fibers in the entire mountainous and northern region.

The Coclé folklorist Elijah Fernandez (pers. comm., Chigoré, 2005) recounted how men at the turn of the twentieth century used a pampanilla of cucua, which he described as a diaper with front and back flaps that hung down; and women wore a refao of cucua, like a towel they wrapped around their waists. This is corroborated by Florentino Morán (pers. comm., San Miguel Centro), who recalls, "Before, one used cucua colorao. Now people don't use it because they don't know how to use it. Before, women would wear a pollera [skirt] of cucua colorao. Men wore a cobo tied with a string, and pantanilla." Florentino Moran (pers. comm., San Miguel Centro, 2005) saw in the 1930s in San Miguel Centro people in quotidian life who wore a rectangular cucua poncho (cobo) that he describes had a round collar with a small triangle in the front. The cloth was folded for storage and was worn with a pantanilla (or pampaniIla) underneath. Everyday clothes were not dyed. He recalls seeing people wearing these and manta sucia cloth until the 1930s. Silvestre Ovalle (pers. comm., San Miguel Centro) confirmed that people in the past would make a long sleeveless shirt, which reached above the knees and was tied at the waist, from a thick cucua colorao or cucua blanco cloth (Iona). Despite not being recognized as Native American within the Panamanian nation-state today, San Miguel Centro villagers freely admit they were indigenous in earlier times and refer to previous epochs as "the time of being indigenous" (cuando eramos indígenas) (Müller-Schwarze 2015).

The power of the nation-state and its policies toward people designated as "indigenous" influenced plant use for clothing. The Victoriano Lorenzo cholos, who fought for indigenous land rights and won a Coclé indigenous reservation in the early Panamanian Republic, wore woven plant-fiber hats (Carles 1966:120). Civilization policies in the early Panamanian Republic required by law that indigenous people wear manufactured clothing (Müller-Schwarze 2015). Nonetheless, Villareal (1992:14) cites a 1964 reference that uses the term cobo for cloth bark dress. Conte Guardia (1963-1964:80) describes how cholos dressed in a cobo, a knee-length habit, and women wore pollerinas, large skirts of various colors, and an adorned jacket called vasquiña, and sees contact through national schools as changing forms of dress. Graciela Joly (1981:37) portrays the removal of festive urban hats that she observed during the northern Coclé utopian movement of the Priestess as a rejection of the outside world. Elder men in La Martillada village, however, recall wearing a suit jacket and tie to dances in an expression of dignity. In the 1980s, the Panamani- an president Manuel Noriega portrayed rural belonging in the nation when he commanded a battalion wherein each soldier used a motete. Ovidio Alveo Nuñez (pers. comm., La Martillada, 2010) recalls that the state asked people in the Azuero to weave their style motete, which has a larger opening than Coclé styles.

\section{The expression of belonging and plant fiber hats}

Scholarly analyses cite plant use data to interpret social belonging and often ascribe belonging to people as groups. Otto Lutz (in Conte Porras No date) describes the pita use for the manufacture of hammocks, bed mattresses, and motetes as a marker of ethnicity and calls the people of northern Coclé "Ngäbe" in his book Los Habitantes Primitivos de Panamá. Durán (2003) equates Coclé people described in Spanish colonial documents with Ngäbe Native Americans today and notes that the name of the provincial capital, Penonomé, reflects the name of a historic cacique or chief. The ethnohistorian Conte Porras $(1999,2003)$ sees wood species that are harvested as a cultural continuity. Conte Porras (1999) cites the Jesuit Juan Franco as having recorded that local people have much valuable plant knowledge to find useful wood and harvest amarillo, almacigo, algarrobo, aguacate, arból de balsa, cocobolo, cacique, caimitillo, caoba, carati, several species of cedro, corotú, espino, espave, guayacán, guachapali, gallito, madroño, membrillo, mamey, nazreno, palo blanco, quira, roble, sigua, and totuma. These are the same common names in use in northern Coclé today (i.e., Müller-Schwarze 2006b). Conte Porras (2001, 2003) interprets Coclé artisan works and the specific uses of the plants from which fibers are manufactured as markers of ethnicity and cites evidence that cholo people have indigenous plant knowledge.

Scholarly interpretation often reflects the narratives of scholars; it is important to consider self-identification and how people describe their social belonging in their own reflections. Narratives in La Martillada village about identification as cholo reflect on clothing and presentation (MüllerSchwarze 2008:176). For example, one respondent recalls that her father told her that in earlier times, both women and men in this area dressed in an underwear made of a bark cambium (cucua). She recalls that people dressed in reused coffee sacks (manta sucia) after the War of a Thousand Days in the early twentieth century, and she noted that no one had access to either clothing or shoes like today. Hennequin sacks were refashioned into clothes, and then white cloth flour bags replaced the manta sucia. Today, people in the village have access to affordable secondhand North American clothing and imported Asian clothing from stores in Penonomé. This reveals the complexities of self-identification practices. Statistical data collected in La Martillada correlate self-identification and use of plant fiber hats within this context; this reflects the location of self within the surrounding ecology (Müller-Schwarze 2008). 


\section{Media narratives about plant fiber use}

Media images are especially revealing about the intersubjective images and stereotypes commonly portrayed about the rural and the indigenous. Panamanian media images promote indigeneity to tourist markets, yet northern Coclé residents have limited land rights (Müller-Schwarze 2015). Media interpretations refer to plant fiber items in national historical narrative and essentialize area residents for the tourism market. Media narratives reviewed here do not refer to specific historical data but rather rely on creative interpretation and the journalist role to uphold a historical narrative for the (Panamanian) nation-state.

People in northern Coclé no longer enjoy indigenous land rights (Müller-Schwarze 2015) yet are essentialized in the common narratives about cucua and crafts in Panamanian media and expression. Narratives in Panamanian media that refer to cucua usually follow these tropes: the "pagan" functions of the dance and conversion of native people (i.e., Rosas \& Ureña 1988, Villareal 1992:10); gender; concern for preservation of plants (i.e., Quezada 2002); cultural and ethnic origins; the spoken verses as resistance to Spanish colonialism (i.e., La Prensa 1985, Racero 2005, Villareal 1992:13); and authenticity (i.e., Espino 2003, No author 2003b, Rosas \& Ureña 1988).

Media narratives seek origin points for cucua practices. Some authors emphasize an indigenous origin for cucua practices, whereas others place the origin at the time of conversion to Catholicism by missionaries. Triana (in Conte Porras 2003) writes that people of Chibchan languages use many plant fibers and cotton; the association of language with material culture can be found in other authors (i.e., Lincoln 2004:49, Romoli 1987). Narratives about origins variously emphasize colonial heritage (i.e., Cesar 2003); indigenous roots (i.e., Valdez 2004, Villareal 1992); ideals of creolization and narratives of acculturation (Torres de Araúz 1992); Coclé regionalism (i.e., La Prensa 2003); and Panamanian national identification (i.e., Josez No date, La Prensa 2005). Villareal (1992:11) describes the designs on the dance outfits as "precolumbian." Beytia Muñoz (No date:67) traces the origins of the eight-syllable copla spoken by cucua dancers to Spanish writers such as Miguel de Cervantes. Plant fiber utilizations are treated as traits comparable with others. Only some authors (i.e., Ariel Rodriguez 2003:8a) seek African roots, in the drums associated with the dance. Rosas and Ureña (1988) describe women participating only in the gaita and the chorro pieces in folkloric presentations and interpret the simple skirt and blouse of women dancers as a recent addition to the dance.

Newspaper articles regularly narrate the story of cucua by crediting specific individuals for their work to preserve the dance (i.e., Quezada 2002, 2003b, 2003c). The teacher Bolivar Ramos claims that the cucua dance originated in Veraguas, and a migration of people from Veraguas to Co- clé brought the dance to the area of San Miguel Centro about six decades ago (Ariel Rodriguez 2003:8a). Pictures of a centennial celebration among the Panamanian diaspora in the United States, held in the Gusman Center in Miami, Florida, refer to the cucua dance as The Dance of the Mirrors (Jarava-González 2002).

Narratives of loss (i.e., No author 2003b) may be based in perspectives formed in the provincial capital Penonomé, as the dance is not performed at Corpus Christi in the city anymore. Such narratives, however, are repeated in a pamphlet prepared by well-meaning outsiders and distributed at performances by the Conjunto Folclórico Candelario Ovalle. Narratives of loss obscure other possible explanations such as migrations of Miskito and Cueva, who hid in mountains during the colonial era and survived in an area of refuge (Müller-Schwarze 2015). For example, in the northern Mosquito Coast, people make bark cloth by pounding with a mallet the inner bark of a Ficus sp. and a Castilla sp. tree, for loin cloths and bed blankets; sorcerers use white "cloth" marked with black and red designs for "incantations" (Conzemius 1932:47). However, understanding of tree cambium cloth as magical is also widespread. Mexican manufacturers of amate paper use Ficus sp. and enact shamanic rituals for the understood magical properties of the paper.

Tourists are attracted by essentialism. A new tourist hotel on the coast of Coclé displays Panama hats and handmade shirts in a glass case, thereby further removing the folkloric image from the reality of life in the countryside (campo), which is a physically challenging life wherein the hat itself protects agriculturalists from long days of labor under the hot sun. Tourist literature recognizes the cucua dance as "indigenous" or Indian, and general knowledge recognizes indigenous roots. Indian stereotypes occupy a special place in the tourist imagination of the exotic. This has implications; the Morán family hosted an unexpected visitor from France interested in cucua who arrived in San Miguel Centro without local language skills and unprepared for rural conditions.

Rural areas are often depicted as uniform and unchanging across entire regions. Anthropological texts (i.e., Conte Guardía 1963-1964, Conte Porras 1963), Panamanian media, and tourism brochures (i.e., Rivera Rodríguez 2009) ascribe cucua as emblematic of the whole region, yet a systematic survey of Indio River watershed (MüllerSchwarze 2008) revealed that none of the respondents reported participation in either fachenda or cucua dances. The Coclé cumbia dance, however, is widespread throughout the region and is danced to music played on a drum, box drum, churuca gourd instrument, violin, and sometimes a guitar. Elders lament the changes, such as heavy influence from Los Santos pindín styles that they perceive have happened in cumbia dances, drumming, and songs. 


\section{Müller-Schwarze - The Arson of a Museum: Ethnography of historical experience and plant fiber use in northern Coclé Province, Panama}

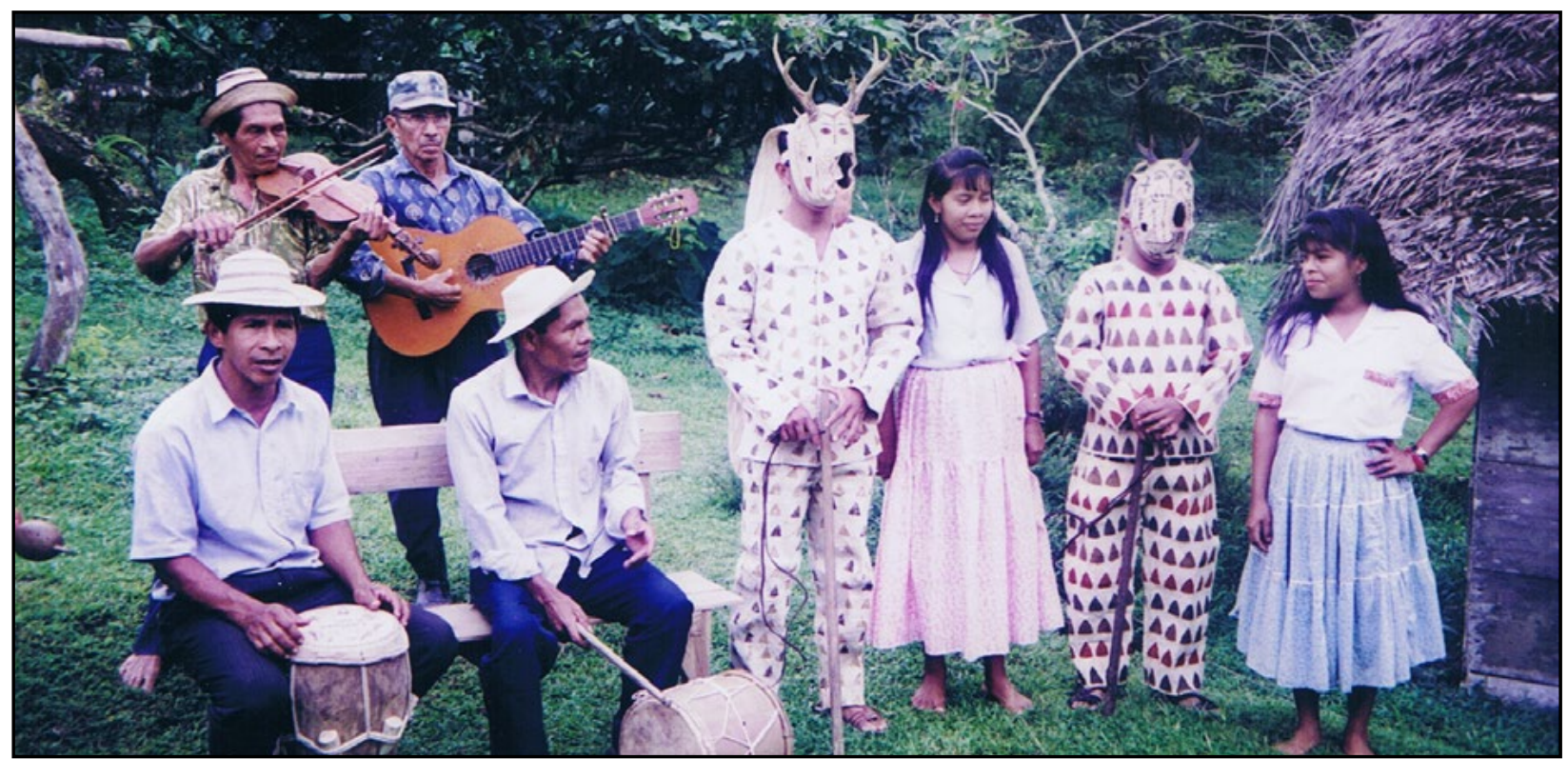

Figure 13. A Peace Corps volunteer in San Miguel Centro encouraged villagers to present the cucua dance to visitors. The musicians Vacilion Morán on violin, Paulino Morán on guitar, Miguel Sánchez on drum, and Herbacio Morán on caja drum accompany the dancers Humberto Morán, Maria Elena Sánchez, Severiano Sánchez, and Juana Helis Morales (from left to right). Maracas are also usually played, but that musician was not present that day. San Miguel Centro, Coclé, Panama, 24 June 2000.

Media authors interpret the functions of the cucua dance to the culture. Ariel Rodriguez (2003:8a) writes that each day is a fight between good and evil for the residents of San Miguel Centro. At the same time, urban Panamanians look to folklore for national belonging. Anthropological scholars have observed how societal norms reverse during festivals, especially Carnival; this can be seen in the Panamanian Carnival celebrations when wealthy urban Panamanians wear clothes from the countryside. Panama hats and campesino handmade shirts are seen at carnival celebrations in the city. It is an interchange of identification, as marginalized country people work to look modern, and wealthy urbanites revel in a romanticized folkloric image of rural life. La Martillada villagers expressed anger in informal discussions and state that such examples show how many urban Panamanians do not know what rural life and work are truly like.

\section{Functions of woven plant items}

In contrast, narratives about plant use in weaving and clothing emphasize function in northern Coclé. Plant fiber bags hung from house rafters for storage are used alongside plastic bags. Many technologies are used at the same time, instead of the expectation that material culture be understood as the "progress" of a linear timeline (Müller-Schwarze 2015). Similarly, the objectification of cucua as cultural artifact differs from understandings about the function of the dance. The folklorist Elijah Fernandez (pers. comm., 2005) understands that people in northern
Coclé had dressed in "bark cloth" in earlier times, but that the cucua dance began in the 1870s. It is possible that he means that the dancers began performing in coastal towns such as Penonomé around this time. The cucua dance can be understood within the context of myths of the Guardian of the Animals, a mythological character whom locals in northern Coclé know to live in specific caves where he protects animals and manages game for hunters (Müller-Schwarze 2015). Elijah Fernandez (pers. comm., 2005) remarks: "The Indian dance is in honor of the animals; the wild pig, deer, the masks are in honor of these animals, the devils interpretation came afterwards, the dance was an Indian refugio for hunting."

Romel Rosas (1998) describes a change in cucua dance emphasis to performance and cites as evidence the innovation that couples dance. Performers dance a friendly cumbia, a northern Coclé circular dance without spoken words around musicians in the center, in presentations for tourists and festivals (Figures 13,14). The cucua dance as performance differs from the community drama that depicts the chasing out of the devil and the banter between the devil and the community; expresses the relation between individual and society; and balances positive and negative. In comparison, basketry from the Darién in Panama is sold in international markets, with a store in Santa Fe, New Mexico, dedicated to it. Wounaan and Emberá basket makers are known for coiling technique of the Carludovica palmata fiber (Indigenous Art from Panamá 2010); designs on baskets are understood to have been 


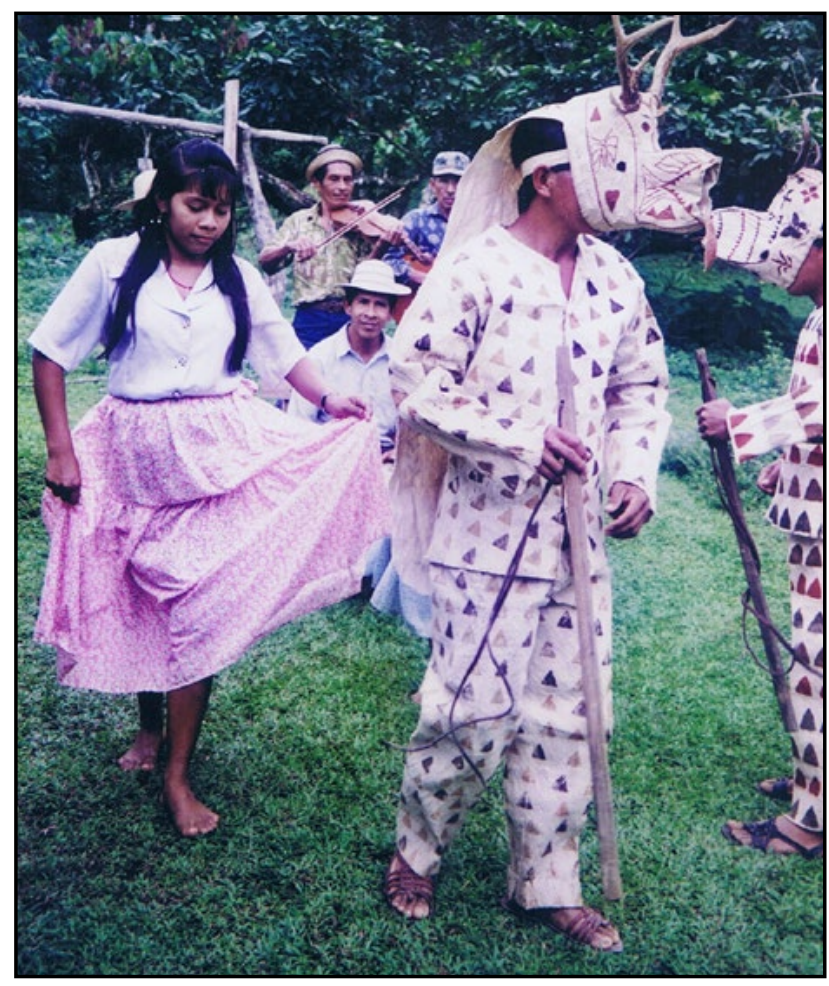

Figure 14. The same musicians and dancers as in Figure 12 present the cucua dance to a group of Peace Corps volunteers in preparation for a redefinition of the dance for a greater public. San Miguel Centro, Coclé, Panama, 24 June 2000.

derived from body painting or curing ceremonies or designs painted on boats and altars to facilitate communication with spirits (Indigenous Art from Panamá 2010).

\section{Functions of the fachenda dance}

Dances are preserved despite being recontextualized in new meanings. Performers today present the dance steps of the fachenda, but not the ritual. Modesto Agraje (pers. comm., San Miguel Centro, 2010) experienced the fachenda as a ritual conducted when a child had died. Elijah Fernández recalls that it was considered taboo to cry or pray for a child under the age of 7 that had died (pers. comm., 2001), as their soul was understood to instantaneously become an angel in heaven. People made a nicho, an arc adorned with flowers and palm fronds inside the house; played songs accompanied with a violin, a guitar, a bell, and a churuca gourd instrument; and danced fachenda in the night and day (Elijah Fernández, pers. comm., 2001). Silvestre Ovalle (pers. comm., 2005) describes the fachenda rituals he experienced as a youth as "a habit and crown for the angel, with a palm cross in hand, the child dressed as an angel. The child lies there as if dead with its hands crossed, surrounded by flowers, and people danced nearby and took a flower each. The godparents of the child were the first to dance; godparents have responsibility like this, to protect a child from anything bad." From there, they took the child corpse to a separate cemetery "for the little angels" that each village had (Elijah Fernández, pers. comm., 2001). He recalls that couples danced fachenda. Silvestre Ovalle describes the dance as part of the grieving ritual (velorio), "It was for the soul of the child to reach heaven-an angel-[we felt] happiness when a child reaches heaven."

Florentino Morán recalls how the child's cadaver would be displayed. The entire community would accompany the family of the deceased child, and people would dance fachenda the whole night instead of sleeping. People would dance fachenda and drink fermented corn again three months later when they observed a ritual wherein a well-dressed doll was strung over an altar and pulled higher to represent the heavenly ascension of the child soul; the three months signify atonement (pagamento) (Florentino Morán, pers. comm., San Miguel Centro). Silvestre Ovalle notes that people have since learned that it is "bad" to dance around a corpse. The Luracito community today dances the fachenda during the annual festival of the Holy Cross in May (Figure 15). Olegario Villareta (recorded interview with Onel Alveo Nuñez, Luracito, 25 July 2006) confirms the preservation of the fachenda dance in Luracito Arriba and that he learned to dance and play the fachenda on violin since he was fourteen. The fachenda musicians in Luracito include violin, guitar, drum, and churuca players, and adults dance fachenda and cumbia on Catholic holy days such as Holy Cross, St. John, St. Peter, and St. Paul (Olegario Villareta, recorded interview with Onel Alveo Nuñez, Luracito, 25 July 2006). In San Miguel Centro, however, dance ensembles that perform in urban areas have adapted the fachenda dance steps to their presentations in performance contexts outside of northern Coclé.

\section{Functions of the cucua dance}

Oral history narratives describe the power available to dancers through cucua practices. The dance made possible the survival of liminal times, such as the disruptions in social structure experienced during Spanish colonialism (Müller-Schwarze 2015). The dance and oral history narratives about cucua practices continue to function as embodiment of historical experience. States create categories through which they govern, and these are usually labeled ethnic and socioeconomic (Müller-Schwarze 2015), yet popular discourse about cucua within Panama emphasizes the creole reality that is expressed in quotidian life in rural areas.

The animal motifs of the cucua dance continued within the colonial context. Blanc (2005) writes that "the dancer is a stage paradigm of what we humans are." Historical context makes the cucua dance necessary as it expresses the embodiment of conversion and colonial- 


\section{Müller-Schwarze - The Arson of a Museum: Ethnography of historical experience and plant fiber use in northern Coclé Province, Panama}

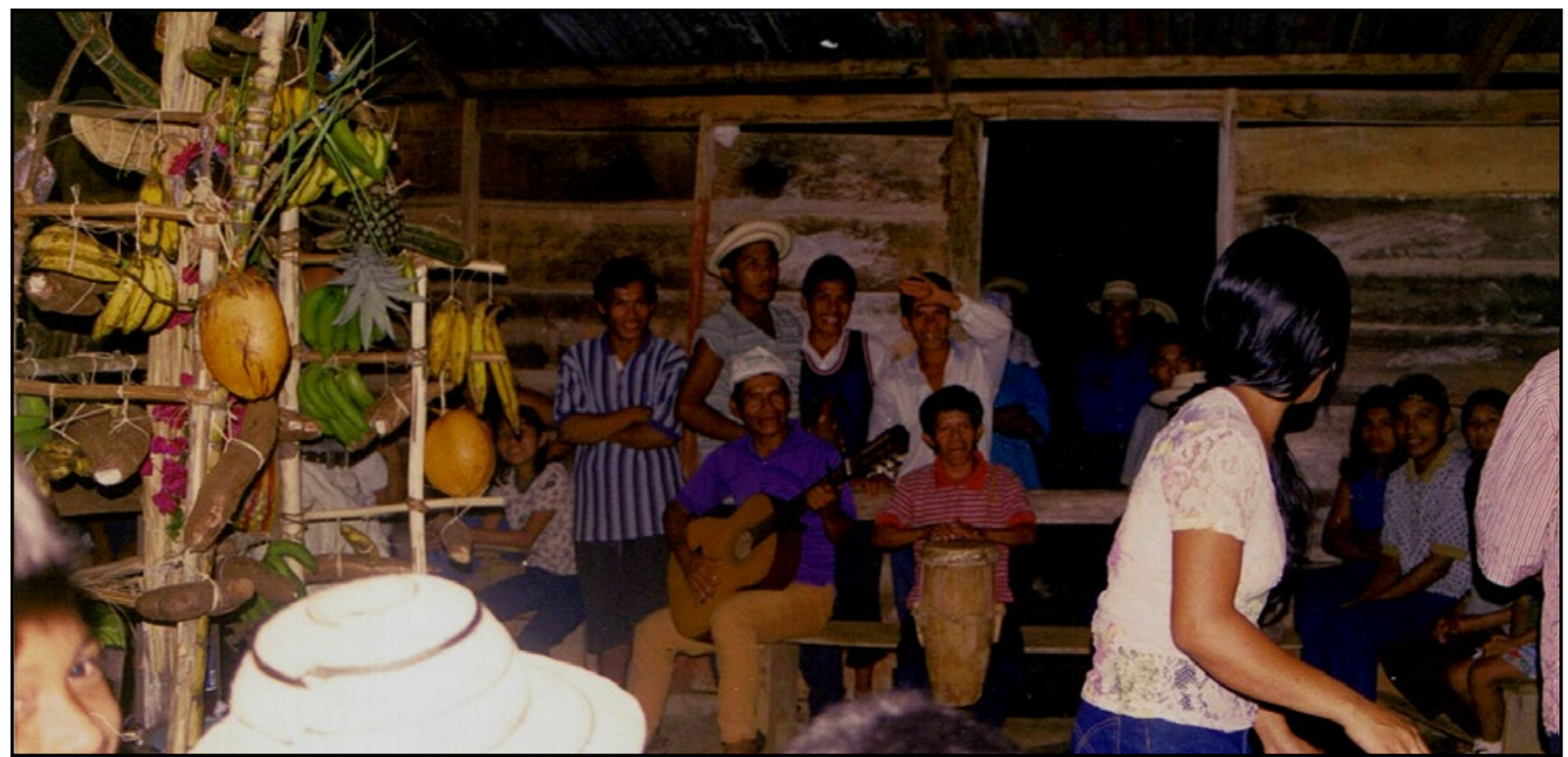

Figure 15. Villagers decorate a cross with local produce and dance the fachenda during the annual festival of the Holy Cross in Luracito, Coclé, Panama, May 2001. A spectator in the foreground wears a handmade hat.

ism. This happened at the Catholic Church building in $\mathrm{Pe}-$ nonomé each year during Corpus Christi. Scholars interpret this particular meaning of the dance with respect to their own feelings toward conversion and conquest. Conte Porras (1988) depicts this dance as a response to colonial structures of power. In the colonial festivities of the Immaculate Virgin, Cu Cua or ñumi dancers descended from the mountains to participate in the festivities; they arrived in Penonomé, as well as in Santa Fe and San Francisco de Veraguas, and this was recognized as a cultural trait and labeled Ngäbe (Conte Porras 1988:133). Conte Porras (1988:133) interprets these dances as indigenous people who demonstrated "resistance" to the colonial Spanish and Spanish-descended, and notes that only later did the town incorporate the dance into its Corpus Christi festival. Scholarly narratives define colonial experiences in their act of interpretation.

Missionaries in colonial times used church theater to convert encountered people and adapted indigenous festivities to Church purposes. In comparison, indigenous voladores dancers perform on Corpus Christi in Mexico. The Spanish festival of Corpus Christi includes the public display of a local church society, the Cofradia, that tends to the saints and to Church business throughout the year. A Belgian nun had initiated Corpus Christi festivities in 1246. The Pope had sanctified it as a festival that took place 62 days after Holy Week, and the festival of transubstantiation became widespread custom in the 1200s. Corpus Christi centers on the ritual consumption of the Eucharist, understood among Catholics as the body of Jesus Christ. Carles $(1947: 35,37)$ remarks that this festival historically received more pomp and festivities in Spain than elsewhere, despite the importance of the Eucharist everywhere in the Catholic world. In the Americas, the festival changed to include encountered people. A document from 1529 (in Asociación Rescate de Danzas Miguel Leguizamo 1996) reports that Corpus Christi was celebrated in the Aztec capital in 1521 and that the procession was led by indigenous dancers that included devils. Ecclesiastical authorities during the Spanish colonial era in Panama organized festivities for Corpus Christi which included parades of troops, dancers, and costumed Indians; dancers portrayed the conquistador Don Pedro Alvarado and the Aztec leader Montezuma (Carles 1947:36). Villareal (1992:11) writes that in 1623, Fray Adrían de Santo Tomás celebrated in Los Remedios with devil dances and that the Spaniard Don Juan de Carrisolio invited caciques to participate in Corpus Christi in Santo Domingo de Darién in 1643 , with church officials organizing these dances.

In Penonomé, the Corpus Christi spectacle of mountain devils dancing included an ever-changing intersubjective negotiation between cultures and religions; in some years the dancers entered into the church building, and in other years Church authorities forbid their entry and they danced outside. This function of the dance, through which town dwellers and mountain indigenous people incorporated and negotiated through theatrical drama the conversion experience, is comparable to descriptions (i.e., Hill \& Monaghan 1987) of the Guatemalan Dance of the Conquest that emphasize the absorption, embodiment, and expression of historical experience (Figure 16). Western church music had in Europe become an event that did not include dance, yet the embodiment of political structures and colonial norms from Europe were reinterpreted by dancers in outfits that expressed both the transubstantiation of earthly experience and the ontology of life with- 


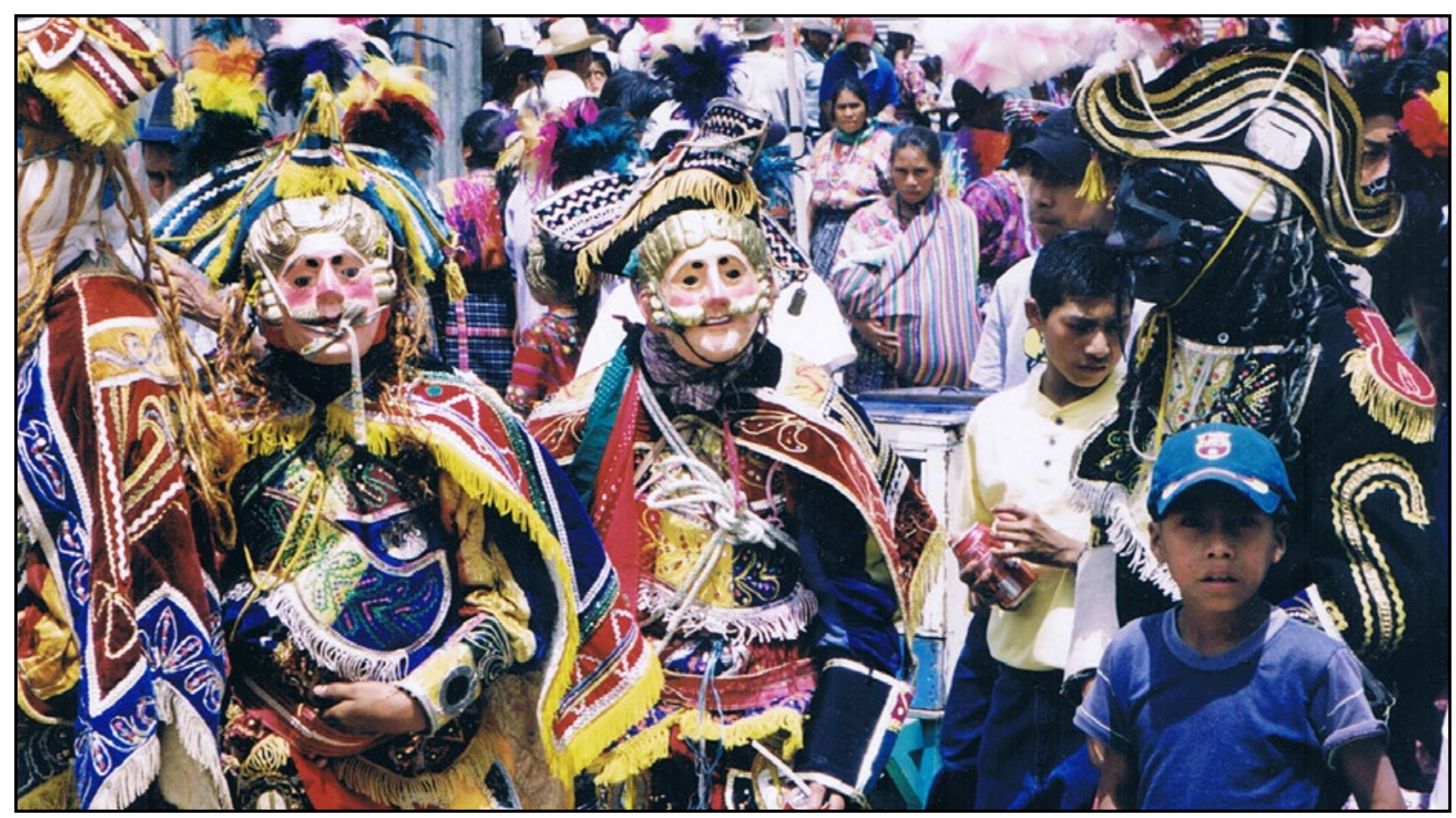

Figure 16. In the Guatemala Mayan Native American village of Santo Domingo Xelajob in 2003, dancers portray the characters of Spaniard and African in the Dance of the Conquest. Scholars have described a function of this dance as the articulation of historical experience, and it can therefore be compared with the function of the cucua dance in Coclé, Panama.

in the surrounding natural environment. The dancers and spectators not only incorporate experience, but also articulate and reinterpret history anew in each performance. Cucua dancers in their interactions with the public improvise in ever-changing comments on social locations. The flexibility of the idiom allows for its survival.

The participation of mountain people in Penonomé church festivals and masses was controversial throughout historical times. Otto Lutz (in Conte Porras 2003) describes Holy Week in Penonomé in 1810 and notes the religious devotion of the cholos who participate in all the activities of the church; however, the festivities ended in a drunken brawl wherein men fought each other to the blood. Eyewitness Tejeira (No date) describes that the diablicos would march into Penonomé in two lines early in the morning on the first day of Corpus Christi celebrations, attend mass, and then follow the procession from the church and stay behind the procession dancing and beating their sticks. $\mathrm{He}$ also describes that the dancers would enter the cemetery looking for souls, which may be a rumor that probably reflects the author's positioning within inherited colonial norms for social relations and attempts to cast cucua as an otherworldly and evil force outside of authoritarian control. In a 2 November 1889 document, the Bishop of Panama reprimanded the Penonomé priest for allowing animal masks and "costumes determined to be of a non-Catholic nature" to participate in the Corpus Christi celebrations
(Conte Porras No date). A series of denuncias during the period 1870-1880 complain about the "indigenous from the mountains" who were allegedly drunk during religious festivals in Penonomé, and there are many documents that show discussion within the church about how much "pagan" expression is allowable in the church during festivals (Conte Porras 1997:143-144). The association of bad behavior with cucua created discussions about proper social conduct in Penonomé town and about the social location of people from the mountains. Cucua practices have in the past repeatedly been that locus of conflict that Mamdani (1996) terms culture. Quezada (2003b) writes that the cucua devils performed in Penonomé Corpus Christi celebrations between 1930 and 1940.

Oral history narrates that the cucua dance was indeed means to live in Spanish colonial times, and how it was revitalized. Florentino Morán recalls, "A tradition of the ancestors, they invited me to dance this. When the Spaniards came here, the dance was a protest. But that was before his time. Although some have died, we have continued this, I want to continue it. We've passed through tough times selling a suit for no more than \$2." Modesto Agraje (pers. comm., San Miguel Centro, 2010) condenses historical time when he recalls his grandfather's explanation and reflects that, after the War of A Thousand Days, mountain people made cucua outfits "just to scare," and that Spaniards feared such outfits and masks, and 


\section{Müller-Schwarze - The Arson of a Museum: Ethnography of historical experience and plant fiber use in northern Coclé Province, Panama}

only afterwards did it become a dance. This may reflect how cucua practices empowered mountain people during colonialism. Similarly, Silvestre Ovalle remarks, "The dance came with the Church, it was a protest against the Spaniards; that they don't invade us. Now we just have the tradition." The dance outfit portrays the conversion experience that brought liberation theology that allowed freedom of the soul despite outer circumstances (MüllerSchwarze 2015). Silvestre Ovalle notes that the Penonomé Church no longer invites San Miguel Centro dancers to participate in Corpus Christi. These narratives show how much power was historically available and continues to be accessed through cucua.

\section{The cucua dance in comparison}

There are many devil characters that take to the streets in other regions of the Panamanian isthmus. Popular culture distinguishes between "dirty" (sucio) and "clean" (limpio) devils. Diablos sucios generally wear red and black colors sewn onto cloth called manta sucia (La Prensa 1985). In earlier times, revelers painted such manta sucia cloth red and black with achiote plant dye and carbon (La Prensa 1985). Oral history narratives recount that a Penonomé priest once painted a devil dancer with a stripe of achiote that ran in the rain, and this outfit was thereafter called "dirty" (Elijah Fernandez, pers. comm., before 2005).

Devil masks across Panama depict animals and often include feathers in their design. Each diablo sucio represents an animal and takes on the characteristics of that animal in the dances at Corpus Christi in Chilibre (Tenorio 1996). Jaen Arosemena (2003:109-110) documents an 1808 Montezuma dance with over 60 actors and sees the origins of the Los Santos Montezuma dance in the Coclé cucua dance: in the circular Montezuma dance Indians and Spaniards confront each other with clashing swords and speak verses, and Indian characters are veiled and imprisoned. In the Montezuma dance, the Cortez character explains in his spoken verses that he comes from the other side of the ocean (No author 2003b); cucua dancers may have inverted this phrase to signify their home in the mountains and as pagan. In Los Santos province, devil dancers metaphorically divide the universe between good and evil, which Coclé cucua do not do in their presentations. Modesto Agraje (pers. comm., San Miguel Centro, 2010) notes that Los Santos devils do not perform dances from Coclé, such as fachenda, cumbia, or chogorro, yet describes as different that they dance to seed noisemakers sewn to their outfits and perform a dance called zapoteo. The San Miguel Centro devil may use bells. Florentino Morán (pers. comm., San Miguel Centro, 2010) describes the dance steps and speech as different, when asked to compare congo dances from Colón province. (The similarity in dance steps and rhythms between Haitian congo and Panamanian congo dances lead one to speculate about the naming of Congo Square in New Or- leans.) Panamanian devils may wear mirrors, and this is popularly explained in that "Spaniards" confused encountered people with mirrors.

Written accounts repeat widespread understandings that locate creative expressions within geographies as origins and historical narratives associated with place (MüllerSchwarze 2013). A collection of articles written for the Panamanian centennial describe cucua dances as national pride. In this article, Jaen Arosemena (2003) repeats Panamanian national historical narrative when he suggests a Mexican origin for Montezuma dances because they depict characters from the encounter between Aztecs and Spaniards, yet he also interprets medieval Spanish traditions in the ties to the church ceremony. European devil dances are seen as having pre-Christian pagan roots in Europe, such as sun rites and fire festivals celebrated in Catalonia (Adolfo Gonzalez, pers. comm.). Morales (2013) interprets the dance of the devils performed in the Mexican states of Guerrero and Oaxaca as ancestral spirits that cleanse evil from villages and that aid shamans in curing. Mayan voladores dancers perform on Corpus Christi, yet also celebrate the solstice and call for rain. Such interpretations of artistic expression attempt to categorize and objectify human life and expression which is flowing and not static. (For example, the influence of aesthetics brought by Asian immigrants to Panama on cultural practices such as urban Panama City devil masks has yet to be described.)

Writers also interpret the function of the performances and locate these within representations of geography. Verrill (1928:218-19) compares the Coclé devil dance to counterparts in South America and describes its function to scare away evil spirits in what he calls "to outdevil the devil." The devil character is found in street theater and festivals throughout Latin America as well as the greater Caribbean. The skeleton character in the New Orleans Mardi Gras has a similar function in scaring away one's fears and reminding viewers that life is short. Wheeler (2006) describes dancing as a Bolivian diablada in a dance that she describes as representing victory over darkness, enslavement, and oppressive forces during the Gran Poder festival in La Paz: "masked, unrecognizable inside 20 pounds of sequins, silver, satin, plaster, glue, elastic: roaring and laughing hellishly." Devil dancers in a Quechuaspeaking town in Peru annually depict evil as humorous personifications of Europeans during the Virgen del Carmen festival (Rommen et al. 2012[2001]:279).

\section{Conclusion}

This article describes intersubjective discourses about plant use, instead of ascribing a label to people portrayed as a "group" (sensu Brubaker 2004). The characters of devil, heathen, and the indigenous overlap in the popular imagination about cucua and empower, albeit during car- 
nivalesque proceedings. Rommen et al. (2012[2001]:281) note that "many stories are being told" within the performances at a festival. Verrill (1928:220) describes the antics of the Coclé dancers in Panama as "frightening" and then notes a holy day as the best day to chase out the devil. The depictions of the surrounding ecology on the cucua dance outfit locate dancers and spectators within a cosmology of plants, sky, and earth. Moreover, cucua practices can be understood within the context of daily plant use in northern Coclé wherein self-location is within the surrounding ecology. Turner (1969) describes the power recognized during liminal times (when societal rules are also reversed) as symbolic, yet the power received through these creative performances is real. The divisions between Church and devils are a continuum; Florentino Morán (pers. comm., San Miguel Centro, 2010) recently gave the Penonomé bishop a pañuelo and a mask. The dances still help mountain people mediate the outside world. Self-understandings in northern Coclé reflect intersubjective spaces among these networks and conversations and show how people manage the lived consequences of national and scholarly discourses.

Plant knowledge and connection to the local environment have repeatedly empowered people who live in the northern Coclé mountains to survive during the Spanish coIonial era when some people avoided plantation life and traded artisan products instead, and now people mitigate economic realities by selling baskets made from plant fibers in the regional Penonomé market or to tourists along the Interamerican highway. It is not specific historical circumstances or the interpretation of origins as ethnic that influence whether plant knowledge and plants are preserved. For example, competition in San Miguel Centro after heightened outside interest in cucua preservation resulted in the destruction of plant resources and the rumored arson of a museum. Rather, adaptation, creativity, and versatility because of functionality have ensured the preservation of plant fiber use and knowledge in northern Coclé and likely elsewhere. The ethnography of historical experience describes the details of the ebb and flow of life lived within nature.

\section{Literature Cited}

Aguilar, J.M. 1963. La población indígena del istmo de Panama. Revista Cultural Lotería 94:73-95.

Ariel Rodriguez, O. 2003. Los cucuás, el alma de San Miguel Centro. La Prensa Domingo Nacionales June 8:8A.

Araúz, C.A. 2002. Provisiones y mercados en el Panamá decimonónico. La Prensa, Ellas October 4:69, 72.

Asociacion Rescate de Danzas Miguel Leguizamo. 1996. Corpus Christi en La Villa de Los Santos 1996. In Conoce
Nuestros Costumbres y Tradicciones. Pamphlet. Archived material, Lotería Nacional de Beneficencia Archive, Penonomé, Coclé, Panama.

Bernstein, B. 2003. The Language of Native American Baskets: From the weavers' view. National Museum of the American Indian, Smithsonian Institution, Washington, D.C., U.S.A.

Beytia Muñoz, A. No date. Nuestra decima y nuestra copla. Pp. 65-68 in Revista Cultural Lotería. Archived material, Lotería Nacional de Beneficencia Archive, Penonomé, Coclé, Panama.

Biesanz, J. \& M. Biesanz. 1955. The People of Panama. Columbia University Press, New York, New York, U.S.A.

Blanc, J. 2005. The creative process. World Dance Alliance Channels Winter:9.

Brubaker, R. 2004. Ethnicity Without Groups. Harvard University Press, Cambridge, Massachusetts, U.S.A., and London, England.

Camargo Ríos, M. 2002. Producción y Comercio en la Sociedad Rural de Penonomé Durante los Primeros Cincuenta Años de la República. Universidad de Panamá: Colección del Centenario, Panama City, Panama.

Carles, R.D. 1947. La Tierra de Los Cholos. Star and Herald Press, Panama City, Panama.

Carles, R.D. 1966. Victoriano Lorenzo: El guerrillero de la Tierra de los Cholos. Panama. Archived material, Lotería Nacional de Beneficencia Archive, Penonomé, Coclé, Panama.

Casimir de Brizuela, G. 1971. Etnografía antigua de Panamá: Visión del hombre y del mundo. Revista Cultural Lotería 192:35-44.

Castillero Calvo, A. 1967. Estructuras Sociales y Económicas de Veraguas Desde sus Orígenes Históricos, Siglos XVI y XVII. Editora Panamá, Panama City, Panama.

Cesar A., R. 2003. Origén de la cutarra. La Prensa June 8:22.

Clifford, J. 1997. Routes: Travel and translation in the late twentieth century. Harvard University Press, Cambridge, Massachusetts, U.S.A.

Conte Guardia, A.M. 1963-1964. El Proceso de Aculturacion del "Cholo Penonomeño". University thesis, Department of Philosophy, Letters, and Education, University of Panama, Panama City, Panama. 


\section{Müller-Schwarze - The Arson of a Museum: Ethnography of historical experience and plant fiber use in northern Coclé Province, Panama}

Conte Porras, J. 1963. Untitled. Archived material, Lotería Nacional de Beneficencia Archive, Penonomé, Coclé, Panama.

Conte Porras, J. 1997. Meditaciones en Torno a Victoriano Lorenzo. Impreandes S.A., Santa Fe de Bogotá, Colombia.

Conte Porras, J. 1998. Panameños Ilustres. Archived material, Lotería Nacional de Beneficencia Archive, Penonomé, Coclé, Panama.

Conte Porras, J. 1999. De los pueblos de Indios en la Jurisdicción de Natá en los siglos XVII y XVIII. Epocas Segunda Era. March. Archived material, Lotería Nacional de Beneficencia Archive, Penonomé, Coclé, Panama.

Conte Porras, J. 2001. Á propósito del Penonomeño y su lenguaje secreto. El Universal June 3:10.

Conte Porras, J. 2003. Los cholos de Coclé de Tomas D. Arias. Epocas Segunda Era July:9.

Conte Porras, J. No date. Nuestro Cholo Coclesano: Dentro de la identidad del ser Panameño. Crónicas del Istmo, El Universal. Archived material, Lotería Nacional de Beneficencia Archive, Penonomé, Coclé, Panama.

Conzemius, E. 1932. Ethnographical Survey of the Miskito and Sumu Indians of Honduras and Nicaragua. Smithsonian Institution, Bureau of American Ethnology Bulletin 106. U.S. Government Printing Office, Washington D.C., U.S.A.

Cooke, R. \& A.J. Ranere. 1992. The origin of wealth and hierarchy in the Central Region of Panama (12,000-2,000 $\mathrm{BP})$, with observations on its relevance to the history and phylogeny of Chibchan-speaking polities in Panama and elsewhere. Pp. 243-316 in Wealth and Hierarchy in the Intermediate Area. Symposium at Dumbarton Oaks, 10-11 October 1987. Edited by F.W. Lange. Dumbarton Oaks Research Library and Collection, Washington, D.C., U.S.A.

Cooper, J.M. 1949. Traps. Pp. 265-176 in Handbook of South American Indians, Volume 5. Edited by J.H. Steward. Government Printing Office, Washington, D.C., U.S.A.

Cordero Pérez, D. No date. Colorantes Vegetales en la Artesania Panameña. Archived material, Lotería Nacional de Beneficencia Archive, Penonomé, Coclé, Republic of Panama.

Davis, W. 1996. One River: Explorations and discoveries in the Amazon rain forest. Simon and Schuster, New York, New York, U.S.A.
Durán, P.E. 2003. Penonomé ó "Be Nu Nomé"? Revista Cultural Lotería 448:76-83.

Espino, B. 2003. Artesano y artesanía. La Prensa June 8:16.

Fernández de Oviedo y Valdés, G. 1478-1557. Historia General y Natural de las Indias. Archived material, Latin American Library, Tulane University, New Orleans, U.S.A.

Figueroa Navarro, A. 1982. Dominio y Sociedad en el Panama Colombiano (1821-1903): Escrutinio sociológico. Editorial Universitaria, Panama City, Panama.

Foucault, M. 1972. The Archaeology of Knowledge \& the Discourse on Language. Pantheon Books, New York, New York, U.S.A.

Graciela Joly, L. 1981. One is None and Two is One: Development from above and below in north-central Panamá. PhD Dissertation, University of Florida, Gainesville, Florida, U.S.A.

Heckadon-Moreno, S. 1996. Estudios botanicos y etnograficos de Henri Pittier en la Costa Arriba de Colón, 1911. Epocas Segunda Era 11(9):2-3.

Hill, R.M. \& J. Monaghan. 1987. Continuities in Highland Maya Social Organization: Ethnohistory in Sacapulas, Guatemala. University of Pennsylvania Press, Philadelphia, Pennsylvania, U.S.A.

Honko, L. 1995. Traditions in the construction of cultural identity and strategies of ethnic survival. European Review 3(2):131-146. dx.doi.org/10.1017/S1062798700001435

Howe, J. 1974. Village Political Organization Among the San Blas Cuna. PhD Dissertation, Department of Anthropology, University of Pennsylvania, Philadelphia, Pennsylvania, U.S.A. http://repository.upenn.edu/dissertations/ AAI7502740

Indigenous Art from Panamá. 2010. Wounaan and Emberá Baskets. www.panart.com/bask_info2.htm. Accessed 10 September 2014.

Jaen Arosemena, D.A. 2003. La danza de 'Los Montezumas' se presento en el Programa Conmemorativo del Centenario de Cocle. La Prensa, Festividades del Centenario September 11:109-111.

Jarava-González, A. 2002. Un espectaculo por el amor al arte. La Prensa, Ellas November 22:42-43.

Josez, F.G. No date. Artesanía de los cucuas. La Prensa, Bienes y Raíces. Archived material, Lotería Nacional de Beneficencia Archive, Penonomé, Coclé, Panama. 
La Prensa. 1985. Enciclopedia de la cultura Panamenya para niños y jovenes. Serie Nuestras Bellas Artes, Vol. 29. La Prensa, Suplemento Educativo Cultural October. Archived material, Lotería Nacional de Beneficencia Archive, Penonomé, Coclé, Panama.

La Prensa. 2003. Dirección general de artesanías nacionales, artesanías representativas de cada provincia. La Prensa June 8:19. Archived material, Lotería Nacional de Beneficencia Archive, Penonomé, Coclé, Panama.

La Prensa. 2005. En busca de la identidad del Panameño. La Prensa, Pulso de la Nacion May 16. Archived material, Lotería Nacional de Beneficencia Archive, Penonomé, Coclé, Panama.

Levinsohn, R. 1980. Rural Kwazulu basketry. African Arts 14(1):52-88. dx.doi.org/10.2307/3335672

Lincoln, K.M. 2004. The Use and Potential of the Pita Plant, Aechmea magdalenae (André) André ex Baker, in a Ngöbe Village: A case study of Chalite, Bocas Del Toro, Panama. M.A. Thesis, Michigan Technological University, Houghton, Michigan, U.S.A.

Lothrop, S.K. 1937. Coclé: An archaeological study of central Panama. Part I: Historical background, excavations at Sitio Conte, artifacts and ornaments. The Peabody Museum, Harvard University Memoirs, Volume VII, Cambridge, Massachusetts, U.S.A.

Lothrop, S.K. No date. Aboriginal Navigation Off the West Coast of South America. Archived material, Latin American Library Archives, Tulane University, New Orleans, Louisiana, U.S.A.

Mamdani, M. 1996. Citizen and Subject: Contemporary Africa and the legacy of colonialism. Princeton University Press, Princeton, New Jersey, U.S.A.

Mason, O.T. 1988 (1904). American Indian Basketry. Dover Publications, Mineola, New York, U.S.A.

Miranda de Cabal, B. 1974. Un Pueblo Visto á Traves de su Lenguaje. Archived material, Lotería Nacional de Beneficencia Archive, Penonomé, Coclé, Panama.

Morales, B. 2013. The Dance of the Devils (La Danza de los Diablos). http://home.earthlink.net/ bettymorales/danza.htm. Accessed 12 March 2014.

Müller-Schwarze, N.K. 2006a. The Cultural Context of Preserving the Coclé Cucua Dance. Paper presented at the World Dance Alliance Global Assembly. Toronto, Canada, 18 July 2006.

Müller-Schwarze, N.K. 2006b. Antes and hoy día: Plant knowledge and categorization as adaptations to life in Panamá in the twenty-first century. Economic Botany 60(4):321-334. dx.doi.org/10.1663/00130001(2006)60[321:AAHDPK]2.0.CO;2

Müller-Schwarze, N.K. 2008. When the Rivers Run Backwards: Field studies and statistical analyses of campesino identity in northern Coclé Province, Republic of Pana$m a$, in the face of the Panama Canal expansion. PhD Dissertation, Department of Anthropology, Tulane University, New Orleans, Louisiana, U.S.A. http://louisdl.louislibraries.org/cdm/ref/collection/p16313coll12/id/3610

Müller-Schwarze, N.K. 2013. Museums and meaningmaking: Historical narratives, baby dolls and teaching voodoo in New Orleans. Collections: A Journal for Museum and Archives Professionals 9(4):353-378.

Müller-Schwarze, N.K. 2015. The Blood of Victoriano Lorenzo: An ethnography of the cholos of northern Coclé province, Panama. McFarland Press, Jefferson, North Carolina, U.S.A.

Museo de Penonomé. 1995. Seminario Taller: Tintes naturales. Instituto Nacional de Cultura. Penonomé, Coclé. Archived material, Lotería Nacional de Beneficencia Archive, Penonomé, Coclé, Panama.

No author. 2003a. Personaje: Diana Julia Chiarí de Gruber. Dirección General de Artesanias Nacionales. La Prensa June 8:3. Archived material, Lotería Nacional de Beneficencia Archive, Penonomé, Coclé, Panama.

No author. 2003b. "Los cucuas" danzan por las calles y plazas de Penonomé, conmemorando el centenario de Coclé. Festividades del Centenario September 11:112113. Archived material, Lotería Nacional de Beneficencia Archive, Penonomé, Coclé, Panama.

Nordenskiöld, E. 1927. The Choco Indians of Columbia and Panama. Discovery 8:347-350.

O’Neale, L.M. 1963 (1932). Yurok-Karok Basket Weavers. University of California Press, Berkeley, California, U.S.A.

Quezada, R. 2002. Tala indiscriminada amenaza baile de cucuá. La Prensa September 29:7a.

Quezada, R. 2003a. Impulsan proyecto forestal. La Prensa August 31.

Quezada, R. 2003b. Construirán casa del diablo cucuá. La Prensa July 24.

Quezada, R. 2003c. La danza de los diablos cucua. La Prensa June 8. 


\section{Müller-Schwarze - The Arson of a Museum: Ethnography of historical experience and plant fiber use in northern Coclé Province, Panama}

Quiros, G.R. 1981. Historia de la Educación en Penonomé. Archived material, Lotería de Beneficencia Archive, Penonomé, Coclé, Panama.

Racero, A. 2005. Los congos de Colón, tradición viva. La Prensa, Nacionales January 30:9A.

Rivera Rodríguez, L. 2009. Los cucuas de San Miguel: Diablos que habitan en las montañas. Panamá Rumbos (17) July 12:36.

Rodríguez, O. 1998. Celebran los 417 años de fundación de Penonomé. La Prensa, Nacionales May 3:7A.

Romel Rosas. 1998. La danza de los cucuas: Una tradición al borde del olvido. La Estrella de Panamá July 3:E7.

Rommen, T., B. Nettl, C. Capwell, I.K.F. Wong, T. Turino, P.V. Bohlman \& B. Dueck. 2012 (2001). Excursions in World Music. Sixth Edition. Pearson, Boston, Massachusetts, U.S.A.

Romoli, K. 1987. Los de la Lengua Cueva: Los grupos indígenas del Istmo Oriental en la época de la conquista Española. Instituto Colombiano de Antropología, Instituto Colombiano de Cultura, Bogotá, Colombia.

Rosas, E. \& C. Ureña. 1988. La danza de los cucuas: Una tradición al borde del olvido. Coclé. El Tucán Revista Turistica Panama.

Suárez, O.J. 1997. La Región de los Llanos de Chirú: Un estudio de historia rural Panameña. Caja de Ahorros, Panamá
Tejeira, G.B. No date. Diablicos Cucuas. Archive 8, Archived material, Lotería Nacional de Beneficencia Archive, Penonomé, Coclé, Panama.

Tenorio, L. 1996. Una tradición singular: Corpus Christi en Chilibre. La Prensa June 9:6A.

Torres de Araúz, R. 1992. Natá Prehispanico. Instituto Nacional de Cultura, Panamá.

Torres de Araúz, R. No date. Algunas Consideraciones Etnográficas e Históricas Sobre el Vestido Cucuá. Archived material, Lotería Nacional de Beneficencia Archive, Penonomé, Coclé, Panama.

Turner, V.W. 1969. The Ritual Process: Structure and antistructure. Aldine Publishing Co., Chicago, Illinois, U.S.A.

Valdez, E. 2004. Danza de los cucuas se mantiene en los pueblos rurales del norte de Penonomé. El Panamá, Provincias May 3.

Verrill, A.H. 1928. Panama of Today. Dodd, Mead and Company, New York, New York, U.S.A.

Villareal, J.B. 1992. La danza de los diablos cucuas. Revista Cultural Lotería January-February:7-25.

Wafer, L. 1960. Translation of a new voyage and description of the Isthmus of America (Viajes de Lionel Wafer al Istmo del Darien [Cuatro meses entre los Indios]). Edited and translated by Vicente Restrepo. Panama City, Panama.

Wheeler, K. 2006. La Paz. O, The Oprah Magazine June:172. 
Appendix 1. Botanical names and local names for plants used in northern Coclé Province, Panama. Linguistic data contained in the northern Coclé dialect names may reflect indigenous pasts.

\begin{tabular}{|c|c|}
\hline Botanical name(s) & Local name(s) \\
\hline Acmella alba (L'Hér.) R.K.Jansen & manzanilla \\
\hline Aechmea magdalenae (André) André ex Baker & pita \\
\hline Anemopaegma orbiculatum (Jacq.) DC. & bejuco de tortuga, tortugillo \\
\hline Anthurium clavigerum Poepp. & bejuco dormilón \\
\hline Apeiba membranacea Spruce ex Benth. or Apeiba tibourbou Aubl. & cortezo \\
\hline Bignoniaceae & bejuco ajo \\
\hline Bixa orellana L. & achiote \\
\hline Bomarea edulis (Tussac) Herb. or Bomarea carderi Mast. & bejuco de acla \\
\hline Brosimum sp. or Naucleopsis sp. & colorao, sandí \\
\hline Calathea panamensis Rowlee ex. Standl. or Calathea marantifolia Standl. & bijao \\
\hline Carludovica palmata Ruiz \& Pav. & bellota \\
\hline Croton draco Schltdl. & sangrillo blanco \\
\hline Curcuma sp. & yuquilla, yuquita \\
\hline Cyperus sp. & junco \\
\hline Desmoncus orthacanthos Mart. & matamba \\
\hline Eleocharis elegans (Kunth) Roem. \& Schult. & esterilla \\
\hline Enterolobium schomburgkii (Benth.) Benth. & corotú \\
\hline Ficus maxima Mill. or Ficus tonduzii Standl. & oreja de puerco \\
\hline Fridericia chica (Bonpl.) L.G.Lohmann & chisna \\
\hline Genipa americana L. & jagua roja \\
\hline Heteropsis oblongifolia Kunth & bejuco mula, bejuco real \\
\hline Manicaria saccifera Gaertn. & guagará \\
\hline Martinella obovata (Kunth) Bureau \& K.Schum. & bejuco colora(d)o \\
\hline Melastomataceae sp. & ojo de gallo \\
\hline Morinda citrifolia L. & guaymí \\
\hline Mucuna mutisiana (Kunth.) DC. & ojo de vena(d)o \\
\hline Nectandra globosa (Aubl.) Mez & sigua \\
\hline Paragonia sp. & bejuco verde \\
\hline Philodendron sp. & bejuco mimbre \\
\hline Pleiostachya pruinosa (Regel) K.Schum. & birutillo, verotillo \\
\hline Poulsenia armata (Miq.) Standl. & cucua blanco \\
\hline Swartzia simplex (Sw.) Spreng. & naranjillo \\
\hline Tanaecium pyramidatum (Rich.) L.G. Lohmann & marica \\
\hline Tetracera volubilis L. & bejuco chumico \\
\hline Xylopia frutescens Aubl. & malagueto \\
\hline
\end{tabular}

